\section{Sistemas complejos y arqueología. Una aproximación teórica al fenómeno urbano}

\section{Complex Systems and Archaeology. A theorical approach to urban phenomenon}

Ismael García Gómez

G.I. Arqueología de la Arquitectura. UPV/EHU. Vitoria-Gasteiz* 1

\section{Resumen}

En este artículo exponemos algunas reflexiones sobre la aplicación del enfoque sistémico en arqueología a partir de la experiencia de nuestra tesis doctoral, que ha tenido como objeto de estudio la ciudad de Vitoria-Gasteiz. Defendemos la idea de que, más allá de las objeciones planteadas desde la arqueología postprocesualista, las nuevas formas de entender los sistemas (Sistemas Emergentes o Complejos), ofrecen una estimulante alternativa para la interpretación en arqueología, alcanzando incluso los significados contextuales.

Palabras clave: Sistemas; Redes; Estructura; Proceso; Geometría social; Análisis multiescala.

\section{Abstract}

This paper intends to reflect upon the application of the systemic approach on archaeology from the experience of our doctoral thesis, whose subject of research has been the city of VitoriaGasteiz. Beyond the objections rose by the post-processual archaeology, the new ways of understanding the systems (Emergent or Complex Systems) offer a stimulating alternative to archaeological interpretation, getting even contextual significances.

Keywords: Systems; Networks; Structure; Process; Social Geometry; Multiscale analysis.

\footnotetext{
* ism.garc@gmail.com

${ }^{1}$ Becario doctoral de Arabarri (Sociedad Anónima de Gestión del Patrimonio Cultural edificado de Álava).
}

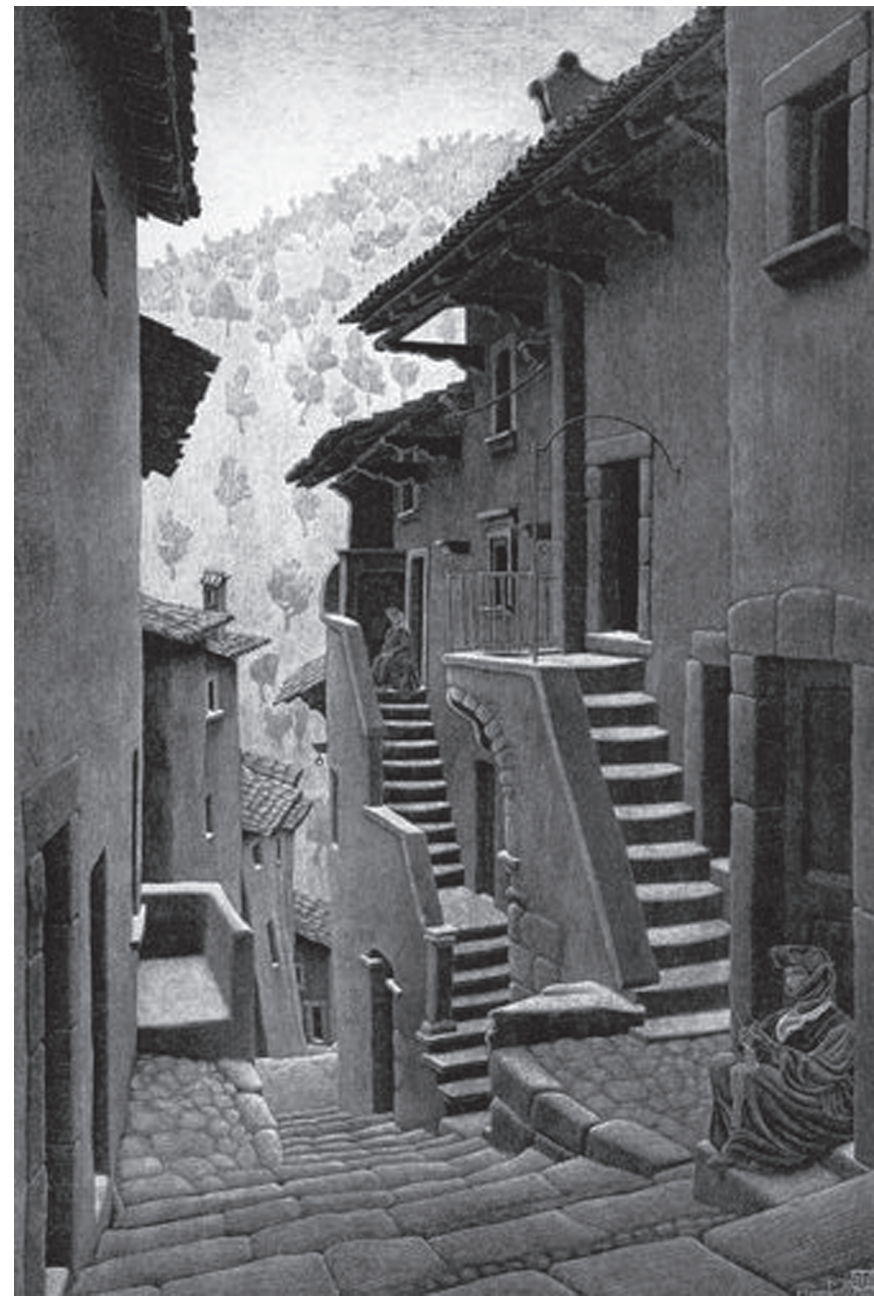

Fig. 1. M. C. Escher, Calle en Scanno, Abruzzi.

"Inútilmente, magnánimo Kublai, intentaré describirte la ciudad de Zaira de los altos bastiones. Podría decirte de cuántos peldaños son sus calles en escalera, de qué tipo los arcos de sus soportales, qué chapas de zinc cubren sus techos; pero sé ya que sería como no decirte nada. No está hecha de esto la ciudad, sino de relaciones entre las medidas de su espacio y los acontecimientos de su pasado (...) Una descripción de Zaira como es hoy debería contener todo el pasado de Zaira. Pero la ciudad no dice su pasado, lo contiene como las líneas de una mano, escrito en los ángulos de las calles, en las rejas de las ventanas, en los pasamanos de las escaleras, en las astas de las banderas, surcado a su vez cada segmento por raspaduras, muescas, incisiones, cañonazos..."

I. Calvino, Las ciudades invisibles.

\section{OBJETIVO: CARTOGRAFIAR LA GEOMETRÍA SOCIAL}

Hace ya algún tiempo que nos encontramos inmersos en la incierta tarea de profundizar en la historia de Vitoria- 
Gasteiz desde un enfoque que consideramos poco habitual, en cuanto que pretende hacer justicia a las múltiples escalas de existencia que la han hecho posible: de las técnicas constructivas a los ciclos productivos; de la unidad estratigráfica al tejido urbano; de la individualidad de los principales personajes históricos a la sociedad; de la función al significado simbólico; en fin, de la sincronía a la diacronía.

Nos estamos refiriendo a la tesis doctoral en la que llevamos varios años concentrados, una investigación que hemos concebido como una suerte de experimento cartográfico, si bien en nuestro trabajo no ha pesado tanto la simple descripción topográfica o morfológica, como el propósito de evidenciar que el tejido urbano es ante todo un sistema, un patrón de organización que se proyecta en el tiempo. Un patrón de organización que no debe ser entendido como una estructura predeterminada (o predeterminante) que se impone implacablemente a la sociedad y al individuo; como creemos podrá comprobarse, comprender los sistemas complejos implica, ante todo, un gran respeto por la capacidad de decisión del individuo o del grupo humano, puesto que son sus iniciativas las que construyen "de abajo hacia arriba» el sistema urbano.

Así, en nuestro enfoque, la arquitectura de una calle no constituye un escenario pasivo sino un sujeto activo, un recipiente receptor y reproductor de relaciones sociales y económicas de diverso tipo. El espacio por ella contenido es un lugar de encuentro, un canal por el que fluyen, y donde se intercambian, objetos e ideas. Al igual que $\mathrm{M}$. Delgado, estamos convencidos de que «más allá de los planes y los planos, lo urbano es otra cosa» (2007: 15) y por ello hemos intentado trascender del puro soporte material que es el urbanismo de una ciudad, para alcanzar los contextos significativos de aquellos que la habitan, la imaginan y la recrean física y mentalmente.

Ahora bien, si la ciudad además de objeto es también una percepción, o una multiplicidad de percepciones - la de los transeúntes que constantemente la recorren (Ibidem: $72)^{2}$ - lo primero que cabría preguntarse es qué pueden tener que ver la Vitoria de Víctor Hugo de $1865^{3}$ con

\footnotetext{
2 "Quienes la recorren -y que no pueden hacer otra cosa que recorrerla, puesto que no es sino un recorrido- basan su co-presencia en una visibilización máxima en un mundo superficial (...) En ese terreno cuenta, ante todo, lo observable a primera vista, lo intuido o lo insinuado mucho más que lo sabido. Consenso de apariencias y apreciaciones que da pie a una construcción social de la realidad cuyos materiales son comportamientos observables y observados, un flujo de conductas basadas en la movilidad cuyos protagonistas son individuos que esperan ser tomados no por lo que son, sino por lo que parecen.» (Delgado, 2007: 72).

3 "Une ville gothique, entière, complète, homogène, como il en reste encore quelquesunes».
}

— por ejemplo— la que actualmente recoge la Wikitravel ${ }^{4}$. Aunque sólo fuera por la distancia temporal, o las distintas perspectivas e intereses que entran en juego, cabría pensar que poco, ¿pero subyacerá incluso en las visiones más dispares un común denominador? ¿Algo que el viajero de cualquier época reconocería inequívocamente como Vitoria? Puede que pequemos de ingenuos, pero - como observa Johnson en el caso de Florencia (2003: 93-94)creemos que la respuesta a tal pregunta no puede ser sino afirmativa. Ese común denominador existe.

No podemos ocultar que, antes de entrar al análisis de los contextos significativos, la mayor parte de nuestro empeño se ha concentrado en el conocimiento somático de la estructura material de la ciudad (por supuesto su arquitectura, pero también su urbanística, su estratificación, profundizando en los modos y técnicas empleados para erigir los muros de los edificios), sin embargo esto no debería conducir al opuesto, para deducir que nuestro interés es más el de analizar el continente que el de comprender el contenido. Hemos buscado un punto de contacto entre ambas realidades, y por ello nuestro objetivo ha sido el de cartografiar con un mínimo de eficacia lo que S. Unwin denominara geometría social: "Cuando la gente se congrega, cada uno identifica su propio lugar de diversas maneras. Al hacerlo asi, cada uno sobrepone una geometría social al espacio en que se encuentra. Como mecanismo de identificación del lugar, la geometría social es arquitectura por derecho propio, pero al tratarse únicamente de interacción entre personas, su existencia es efimera. Las obras de arquitectura pueden responder a geometrías sociales, ordenarlas, y hacer que su definición fisica sea más permanente» (2003: 113).

\section{NUESTRAS REFERENCIAS: UN EJEMPLO DE CAUSALIDAD CIRCULAR ${ }^{5}$}

\subsection{Un punto de partida}

Los riesgos asumidos con tal enfoque no son pocos a nuestro juicio. Para empezar, porque si no logramos dar con la fórmula adecuada para transmitir nuestra percepción (por ejemplo en este artículo), el potencial que atribuimos a la idea de la visión de sistemas emergentes,

\footnotetext{
${ }^{4}$ "Capital de la Provincia de Álava y capital también de la Comunidad Autónoma del País Vasco. España».

${ }^{5}$ A partir de este epígrafe y a lo largo del artículo se hará referencia a diversos títulos tanto en inglés como en español. La elección del idioma para la cita no depende de la edición original sino de la lengua de la edición consultada por el autor. Del mismo modo, para las fechas de las distintas obras mencionadas, se optará por la data de la edición utilizada.
} 
puede ser interpretada como un mero subterfugio con el que acaso habríamos tratado de cohesionar elementos que en esencia poco o nada tienen que ver entre sí. Para seguir, porque, aunque se perciba una cierta omnipresencia del enfoque arqueológico, nuestra forma de analizar el fenómeno urbano de Vitoria, no se cimienta en exclusiva sobre la Arqueología; el análisis de este tipo de cultura material ha implicado por descontado a la Arquitectura, a la Historia del Arte, y como no, a la historiografía del documento escrito. Todas estas disciplinas tienen tanto que ver en el producto final, que el encuadre de nuestra investigación dentro de un ámbito de conocimiento específico resulta muy difícil; esperamos que esto sea apreciado por el lector más como una cualidad que como un defecto.

Por otro lado, el grado experimental del enfoque planteado aconseja alejarse de pretensiones que vayan más allá de las meramente propositivas. Es verdad que, de algún modo, creemos estar planteando un marco de trabajo dotado de una cierta originalidad, pero desearíamos que nadie viera en estas líneas un postulado formal con vistas a superar anteriores paradigmas. De hecho, aunque este fuese nuestro deseo, no tendríamos más opción que rendirnos ante los límites de nuestra propia capacidad expresiva y reflexiva.

En cualquier caso, ha sido precisamente la naturaleza de los riesgos asumidos al adoptar este enfoque la que ha hecho que, desde un primer momento, nos hayamos sentido identificados con algunos de los planteamientos que se están abriendo paso últimamente en la arqueología moderna: nos referimos en concreto a aquél que recientemente ha sido conceptuado por G.P. Brogiolo como Arqueología de la Complejidad (2007). Nuestro «viaje hacia la complejidad» ha discurrido por cauces distintos ${ }^{6}$, hasta el punto de que es bastante probable que al completar la revisión de este artículo el lector llegue a la conclusión de que nuestra complejidad y la de Brogiolo tienen poco que ver (como de hecho nosotros mismos creemos).

Epistemológica y metodológicamente, nuestro trabajo hunde sus raíces en la noción de Arqueología de la Arquitectura que, a grandes rasgos, cristalizó con el Seminario Internacional celebrado precisamente en Vitoria en Febrero de 2002. En él, los congresistas participantes convinieron en reivindicar — si cabe con mayor decisión que en anteriores ocasiones - la lógica estratigráfica como clave de lectura del hecho construido, pero sobre todo $-\mathrm{O}$ al menos es otro de los aspectos que más destacaríamos- también

${ }^{6}$ Debemos dejar bien claro que el horizonte metodológico propuesto por el investigador italiano nunca formó parte de nuestras premisas de partida, de hecho no tuvimos conocimiento de su formulación hasta una etapa muy avanzada de nuestras investigaciones. postularon que la Arqueología de la Arquitectura debía empeñarse en la formulación de nuevos problemas históricos y la creación de nuevos ámbitos de investigación (Azkarate et alii 2002: 8). Convencidos de esto último, nos hemos dejado llevar hasta cierto punto por el propio objeto de estudio - la ciudad—, adaptando y reformulando experiencias pasadas con tal de conseguir un conocimiento más profundo, basado en el máximo respeto al modelo de racionalidad que el propio contexto urbano nos imponía ${ }^{7}$.

Nuestra visión surge también, aunque quizá de forma menos evidente, de los planteamientos post-procesuales de I. Hodder, en la medida en que concedemos gran importancia al significado contextual y entre nuestros objetivos está el intentar sintetizar ciertas dicotomías que creemos que son hasta cierto punto ilusorias; relación entre norma e individuo, entre proceso y estructura, entre lo ideal y lo material; entre sujeto y objeto (1994: 166-176). Para ello, seguiremos algunas de las propuestas de los propios críticos al procesualismo y a la teoría de sistemas clásica, como son C. Tilley, o M. Shanks, quien ya hace casi dos décadas propuso el 'rhizomes-thinking' como una alternativa al imperante 'tree-thinking': "en un rizoma, nunca te sientes seguro ante una división binaria o una dicotomía; la división puede volver sobre si misma con una nueva organización, reiniciando la secuencia» (1991: 35). En esta línea, no podemos olvidar la Social Archaeology of Houses de R. Samson y de T. Saunders de quienes tomamos algunas ideas que creemos han sido directrices en nuestras investigaciones sobre el urbanismo vitoriano: "Para superar este falso dualismo entre forma y contenido, el espacio activo o pasivo, debemos reiterar la premisa básica de que las estructuras espaciales son simultáneamente el medio y el resultado de la acción humana» (1990: 183).

\subsection{Una presunta revolución}

Con todo, lo hasta aquí expresado aún sólo describe parcialmente las bases de nuestra perspectiva; acaso su "prehistoria», porque hace aproximadamente cuatro años, dos lecturas al margen de nuestros habituales intereses disciplinares venían a transformar radicalmente la forma en que hasta entonces concebíamos la Arqueología y el modo en que «leíamos» la cultura material ${ }^{8}$. Dichas obras,

\footnotetext{
${ }^{7}$ F. Criado propone, como segunda fase de su método interpretativo, introducir significado en las interpretaciones mediante un modelo contextual, es decir, adoptando "como referencia interpretativa (como horizonte de inteligibilidad de la interpretación) un modelo de racionalidad que sea el del contexto original de lo interpretado" (2006: 250).

${ }^{8}$ Este cambio creemos que se aprecia al comparar los otros artículos que hemos publicado en esta misma revista (García Gómez, 2003; Azkarate y García Gómez, 2004).
} 


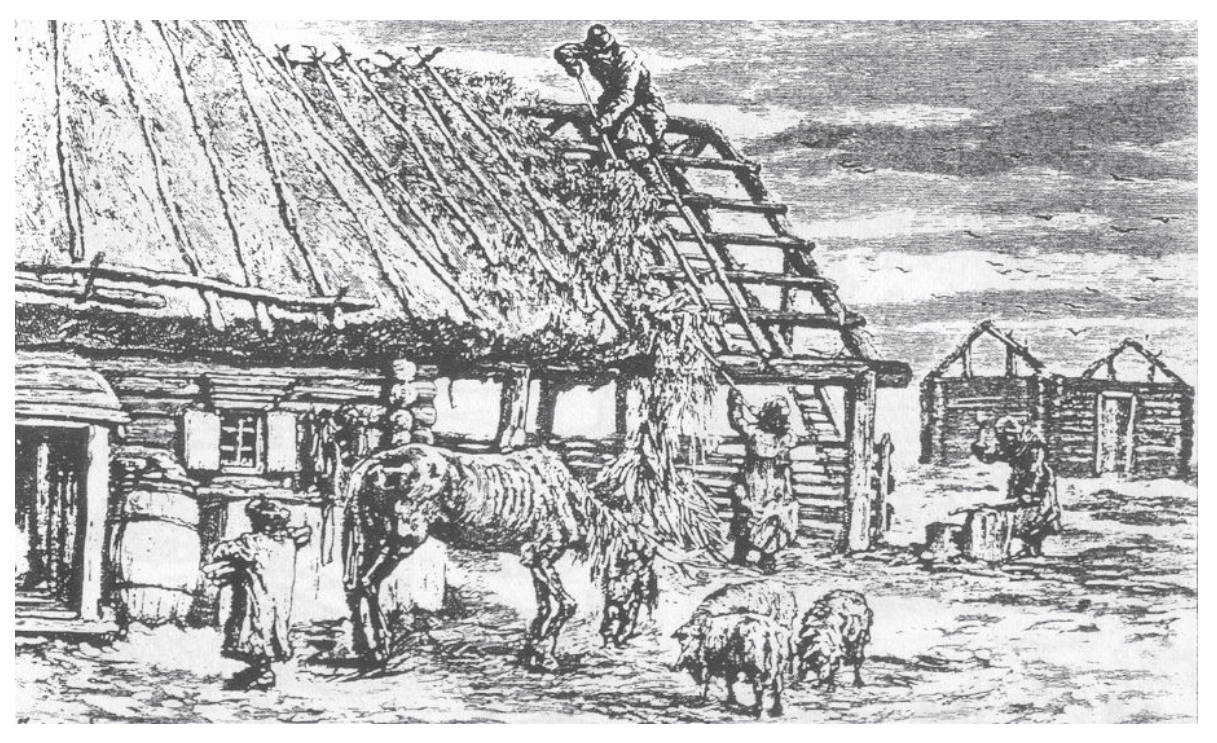

Fig. 2. Visión termodinámica del edificio. «La energía solar que atraviesa el vidrio o la energía fósil que se consume en la estufa hacen el edificio habitable para los seres vivos que en él se albergan; $y$ los propios materiales que lo forman no son sino energía acumulada, como muestran elocuentemente los campesinos que, amenazados por el hambre, alimentan al ganado con la paja de sus tejados» (Fernández-Galiano, 1991: 25) aunque nos abrían al campo del pensamiento de sistemas complejos, no desplazarían las ideas hasta entonces asumidas, antes bien, les dotaron de un sentido más preciso, potenciándolas. Hablamos de «Sistemas emergentes. O qué tienen en común neuronas, hormigas, ciudades y software» de S. Johnson (2003) y de "La trama de la vida. Una nueva perspectiva de los sistemas vivos» de F. Capra (1998). Las dos obras recogen en síntesis los conceptos básicos de lo que Capra denomina una "visión holistica del mundo" o también una "visión ecológica»?

En un primer momento, nuestra propia ignorancia nos hizo pensar que aquella aparente novedad constituía una verdadera revolución, pero pronto nos dimos cuenta de que se trataba de un marco conceptual que contaba con un largo recorrido y que de hecho ya había sufrido numerosas y furibundas críticas desde que L. von Bertalanffy publicara su "Teoría de los Sistemas» allá por 1968 (entre aquéllas habría que destacar la del propio Hooder, 1994: 33-48).

No mucho después llegó otra lectura fundamental que nos sirvió como puente para conectar el apenas descubierto "universo» sistémico con el hecho arquitectónico; «El fuego y la memoria. Sobre arquitectura y energía». En esta

\footnotetext{
9 El término «ecológico» se utiliza aquí en un sentido mucho más amplio y profundo de lo habitual. En síntesis el término pretende hacer hincapié en la visión del mundo, no como una colección de objetos aislados, sino como una red de fenómenos fundamentalmente interconectados e interdependientes. "Los términos 'holistico' y 'ecológico' difieren ligeramente en sus significados (...) Una visión holística de, por ejemplo, una bicicleta significa verla como un todo funcional y entender consecuentemente la interdependencia de sus partes. Una visión ecológica incluiría esto, pero añadiría la percepción de cómo la bicicleta se inserta en su entorno natural y social: de dónde provienen sus materias primas, cómo se construyó, cómo su utilización afecta al entorno natural y la comunidad en que se usa, etc.» (Capra, 1998: 28).
}

obra, L. Fernández-Galiano (1991) profundizaba en ciertas cuestiones (como la clave termodinámica para el análisis del edificio, y la concepción de éste como sistema termodinámico abierto que se debate entre ciclos anabólicos de construcción y catabólicos de disgregación, Fig. 2) que nos eran extrañamente familiares. No había sin embargo nada de qué sorprenderse, pues no en vano se trata de conceptos fundamentales para la comprensión de la génesis de la estratificación, como explícitamente señalaban E.C. Harris en su "Principios de Estratigrafía Arqueológica» (1979) y A. Carandini en su "Historias en la tierra. Manual de excavación arqueológica» (1991).

Fue precisamente al cerrar este, digamos, «círculo» (de la arqueología a los sistemas, de los sistemas a la naturaleza termodinámica de la arquitectura, y de ésta de nuevo a la arqueología), cuando empezamos a considerar que podría ser interesante experimentar y tratar de aplicar este diverso bagaje conceptual al análisis e interpretación del hecho urbano. Sin embargo, aún cabía una duda fundamental; teníamos bastante claro que el enfoque de sistemas complejos podía ayudarnos a comprender y decodificar la estratificación y la conformación arquitectónica de los edificios históricos ¿pero nos ayudaría efectivamente a alcanzar los aspectos sociales? ¿los significados contextuales?, es decir, más allá del continente, ¿nos permitiría comprender el contenido?, ¿hasta qué punto debíamos zambullirnos en el, según Capra, «nuevo paradigma»?

\subsection{Un retorno}

De nuevo, otra importante lectura vino a matizar nuestras reservas. Hablamos de "El paisaje de la historia. Cómo los historiadores presentan el pasado», una obra en la que el 
historiador J. Lewis-Gaddis ponía de manifiesto que, paradójicamente, los más avanzados conceptos en la ciencia de los sistemas y la complejidad, ya estaban implícitos en la historiografía tradicional, mucho antes incluso que en los campos experimentales: "nuestros métodos han sido más sofisticados que nuestra conciencia de ellos, nuestra práctica ha sido mejor que nuestra epistemología" (2004: 127). Gracias a Lewis-Gaddis, comprendimos que no era necesario cambiar sustancialmente el marco interpretativo en el que habitualmente nos habíamos venido moviendo como historiadores y arqueólogos. La base en principio era buena, acaso bastaba con un mínimo reciclaje —en gran medida terminológico- que nos sirviera para establecer paralelos razonables entre las estructuras urbano-arquitectónicas, las sociales y los distintos contextos de significado, entre el lenguaje propio de las ciencias experimentales y el de las humanas. De algún modo era como volver al principio ¿perdía entonces su sentido el largo «periplo sistémico» que apenas habíamos completado? ¿fue una travesía en balde? Creemos que no, el itinerario epistemológico arriba esbozado nos sirvió para tomar consciencia; ahora conocíamos las bases teóricas de los principios que hasta entonces aplicábamos de forma mecánica.

En ese proceso de continuo reciclaje metodológico - y fijando cada vez con más decisión la ciudad como objeto preferente de estudio- M. Delgado y K. Schlögel, autores, respectivamente, de «Sociedades movedizas. Pasos hacia una antropología de las calles» (2007) y de "En el espacio leemos el tiempo. Sobre Historia de la civilización y Geopolítica» (2007) constituyeron un importante revulsivo. Delgado con su no-ciudad, nos aportó una estimulante visión de la sociedad como creadora de espacios urbanos (su sociedad de miradas, su cultura de las aceras, o sus coaliciones peatonales forman parte fundamental de nuestro modo de entender el fenómeno urbano). Schlögel, por su lado, nos proporcionó múltiples e imprevistas formas de entender y leer planos, las cuales, a nuestro juicio, superaban con mucho las lecturas que habitualmente se hacen desde la urbanística, la arqueología y la propia historiografía ${ }^{10}$.

\section{EXPERIENCIAS DE PENSAMIENTO SISTÉMICO}

En cualquier caso, es claro que no somos los primeros en recorrer la senda, digamos, sistémica a la hora de estudiar el

\footnotetext{
${ }^{10}$ Para Schlögel todo material es susceptible de convertirse en fuente documental: "Todo cuanto en otro caso se utiliza sólo como recurso auxiliar, guías de itinerarios, listines telefónicos y directorios, ganan una fuerza expresiva totalmente nueva tan pronto se los trata y se les interroga como a documentos 'sui generis'. Nos abren espacios de ciudades arruinadas y despliegan ante nosotros movimientos grandes y complejos que hace ya mucho se pararon: coreografias de trato humano, guiones de socialización humana» (2007: 17).
}

fenómeno urbano. Amén de aquellos conceptos y métodos de análisis que de forma más o menos evidente han ido impregnando los discursos interpretativos de historiadores y arqueólogos de la ciudad, existen no pocos ejemplos de enfoque explícitamente sistémico. Podemos poner sobre la mesa el trabajo de Y. Barel «La ciudad medieval. Sistema social-Sistema urbano» (1975), una aportación en nuestra opinión interesantísima, pero que sin embargo no tuvo mucho eco (quizá precisamente por la dificultad de encuadre dentro de una esfera de conocimiento concreta). Obsérvese también el modo en que G. Bois afronta el análisis de la crisis bajomedieval en "La gran depresión medieval: siglos XIV-XV. El precedente de una crisis sistémica" (2001).

En Arqueología, la teoría general de sistemas ocupó un lugar relevante del debate disciplinar ya a finales de los 60 y durante los 70 , fundamentalmente gracias a los trabajos de un nutrido grupo de investigadores encabezados por K.V. Flannery, autor de la clásica referencia "Archaelogical systems theory and early Mesoamerica" (1968). Los presupuestos sistémicos se mantuvieron con cierta vigencia hasta bien entrados los 80 , siendo quizá "Arqueología, una ecología del hombre» de K.W. Butzer (1982) la obra donde, de forma más explícita, quedó reflejado el sustrato de pensamiento sistémico —el mismo que luego perviviría en la llamada Arqueología Espacial o Ecológica- Los años 90 fueron sin embargo años de la revisión post-procesualista, que vieron como los sistemas en arqueología caían en un cierto descrédito, a pesar de que algunos de los principales críticos sólo pretendían, por así decir, un replanteamiento de objetivos, sobre todo una corrección del excesivo acento funcionalista: «Las necesidades del sistema social no pueden ser independientes de los actores que lo forman, de modo que la noción de función de sistema o la función de los rituales $u$ otras prácticas institucionalizadas es completamente irrelevante» (Shanks y Tilley, 1992: 119).

Con todo, las ideas sistémicas en ningún momento han dejado de formar parte del pensamiento arqueológico actual. Casi subterráneamente, han pervivido en los modelos interpretativos de la última década, aflorando puntualmente en el contexto de modelos interpretativos que no necesariamente se reconocen —no tienen por qué- como deudores de la teoría clásica de sistemas. Los ejemplos son variados, pero en nuestra opinión cabría destacar trabajos como "Arqueología de la Producción», de T. Mannoni y E. Giannichedda (2004), donde los conceptos de sistema y de ciclo constituyen una base argumentativa fundamental. A pesar de lo diluido que ha quedado el legado de los 
sistemas después de las reformulaciones post-procesuales, no creemos que haya nada de que lamentarse. En nuestra opinión, el caldo de cultivo epistemológico en estos últimos años ha sido razonablemente fértil y sobre todo ha logrado rescatar al individuo, los significados contextuales y la dimensión simbólica.

Este renovado bagaje sin duda seguirá enriqueciéndose. Creemos que la Arqueología de la Arquitectura está en disposición de contribuir aún más en este sentido, quizá adoptando las estimulantes aportaciones de la Arqueología del Paisaje. Sistemas de representaciones, patrones de racionalidad y de organización, múltiples niveles de articulación espacial, etc. (Criado, 1999: 10), son conceptos que articulan la metodología interpretativa propuesta por esta última disciplina, en la que no podemos evitar apreciar ecos del pensamiento sistémico. Éstos quizá resultarían irreconocibles a ojos de los investigadores que hasta los años 80 aplicaron tales presupuestos, pero desde la nueva perspectiva de los sistemas complejos, es como si algo, poco a poco, volviese a tomar forma, volviese a adquirir coherencia; algo mestizo, algo nuevo pero que, en parte, recuerda a lo que había.

\section{ALGUNOS CONCEPTOS DEL PENSAMIENTO DE SISTEMAS COMPLEJOS}

Ahora bien, ¿̇en qué consiste más concretamente el pensamiento de sistemas complejos?, ¿qué puede aportar al estudio de una ciudad como Vitoria-Gasteiz? Probablemente para responder a estas preguntas deberíamos hacer una exhaustiva retrospectiva que recogiera, siquiera síntéticamente, la evolución del pensamiento en diversos campos a lo largo de las últimas décadas, sin embargo hemos creído más adecuado el ceñirnos a aquellos aspectos que, surgidos en el contexto de nuestro proceso de investigación han contribuido efectivamente a estructurar el enfoque con el que, personalmente, percibimos el fenómeno urbano.

En este punto del discurso, nuestra situación es justo la contraria a la descrita por T. S. Kuhn en «La estructura de las revoluciones cientificas»: "cuando un cientifico individual puede dar por sentado un paradigma, no necesita ya, en sus trabajos principales, tratar de reconstruir completamente su campo, desde sus principios, y justificar el uso de cada concepto presentado.» (2001: 47). En nuestro caso, no podemos dar por sentado paradigma ecológico o sistémico alguno en la medida en que percibimos que se trata de un enfoque en plena discusión dentro del área de conocimiento en que nos movemos. Es por ello que este artículo responde sobre todo a la necesidad personal que sentimos como investigadores de explicitar nuestras fuentes metodológicas y episte-

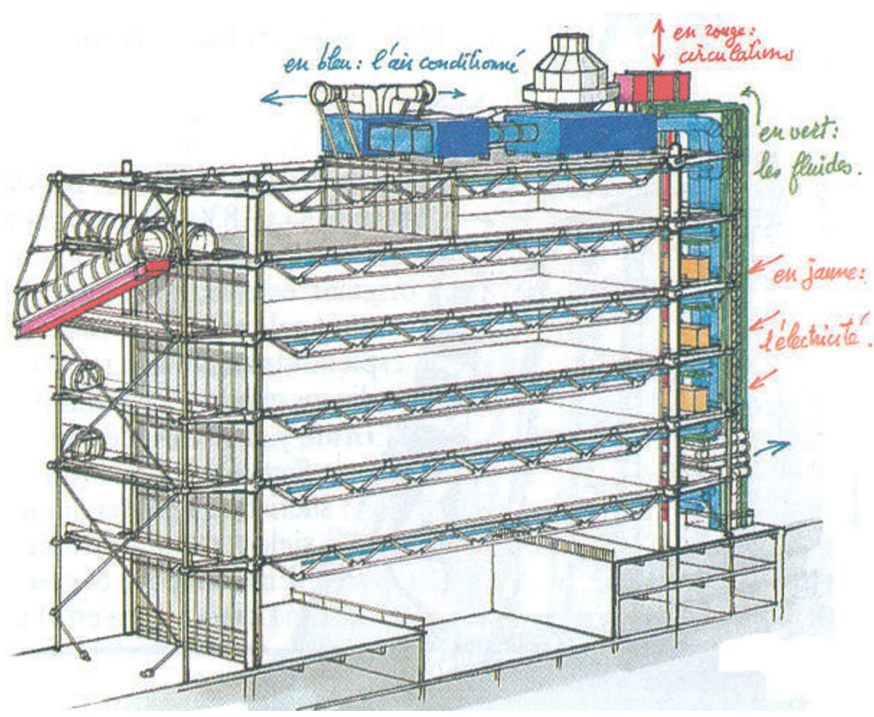

Fig. 3. Sección del Centro George-Pompidou de París. La arquitectura de este edificio se caracteriza por invertir los términos habituales, mostrando al exterior, los elementos sustentantes, las escaleras mecánicas o los conductos de ventilación y calefacción. Los colores de las viguetas y conductos corresponden además a la función que cumplen: azul para el aire acondicionado, verde para los fluidos, rojo para los transportes y amarillo para la corriente eléctrica

mológicas, exponiéndonos a la crítica. Dentro de nuestras posibilidades, estamos tratando de responder al reto que plantea Lewis Gaddis: "Mi cuarto objetivo es alentar a mis colegas historiadores a explicitar más sus métodos. Normalmente nos resistimos a ello. Trabajamos en el seno de una amplia variedad de estilos, pero en todos ellos preferimos que la forma oculte la función. Nos espanta la idea de que nuestra escritura imite, por así decirlo, el diseño del Centro Pompidou de París (Fig. 3), que pone con orgullo sus ascensores, tuberías y cables 'fuera' del edificio, a la vista de todo el mundo. No cuestionamos la necesidad de esas estructuras, sino sólo el impulso a exhibirlas» (2004: 11).

Hablar de enfoque sistémico en arqueología puede dar la impresión de dejà $v u$, o puede resultar directamente un anacronismo si consideramos las críticas de Hooder (1994: 33-48), de Shanks y Tilley (1992), o del propio Criado (1993) como punto final y superación del mismo. La cosa posiblemente no fuera para menos, pues por ejemplo Hooder advertía, no sin razón, importantes debilidades en los marcos interpretativos de los arqueólogos que según él se englobaban dentro de la corriente sistémica ${ }^{11}$; repitamos, infravaloración de los significados históricos, rol pasivo del individuo, acusado funcionalismo, etc.

Con todo, Hooder advertía que el problema del enfoque de sistemas no era tanto su planteamiento como su puesta en práctica, reconociendo incluso que en un cierto

${ }^{11}$ Wobst, Flannery, Marcus, Sherratt, Randsborg, etc. 
sentido «el pensamiento sistémico sí es contextual» (1994: 46). Las críticas más fuertes se centraban quizá en dos aspectos clave; la incapacidad para abordar los significados simbólicos y la atemporalidad atribuida a la actividad humana "como producto de las interacciones sistémicas, y no como un producto histórico» (1994: 47-48). En nuestra tesis doctoral trataremos de demostrar que, como de hecho algunos autores ya apuntan (Bintliff, 2004: 187), los objetivos, digamos, post-procesuales, pueden ser también satisfechos desde los sistemas. No obstante, la razón de este artículo es otra; partimos de una impresión — que el enfoque de sistemas se ha renovado (bien es verdad que en el seno de disciplinas ajenas a la arqueología) - y pretendemos plasmar la intuición de que merece la pena volver a tomarlo en consideración bajo un nuevo e integrador prisma: el de los sistemas complejos (o emergentes si se prefiere) ${ }^{12}$.

Pues bien, a continuación intentaremos sistematizar en diez puntos (podrían haber sido unos cuantos más), los aspectos fundamentales del renovado pensamiento sistémico, o al menos aquellos que, de forma más determinante, han venido a estructurar nuestro método de análisis del fenómeno urbano. Por supuesto, tomados uno por uno, ninguno de estos aspectos es privativo del enfoque de sistemas complejos - muchos proceden, como no, de la teoría clásica de sistemas, o son comunes a otras escuelas de pensamiento- , pero creemos que esto no impide admitir la originalidad del conjunto. Por otro lado (aunque quizá no es necesaria la advertencia), muchos de los autores citados en los distintos epígrafes no se reconocen ni explícita ni implícitamente dentro de una supuesta corriente de sistemas; sencillamente recurrimos a ellos para recalcar que el pensamiento de sistemas complejos está presente entre nosotros, aunque no lo reconozcamos como tal.

\subsection{VISIÓN HOLÍSTICA Y CAUSALIDAD}

El mundo y la historia no pueden entenderse como una colección de objetos aislados, seriados o secuenciados de un modo más o menos lógico, sino como una red de fenómenos fundamentalmente interconectados y completamente interdependientes. Frente a las visiones mecanicistas, el enfoque sistémico concibe a los propios objetos como redes de relaciones inmersas en redes de relaciones mayores. Para el pensador sistémico las relaciones son prioritarias (Capra, 1998: 29 y 57). Ahora bien, si todo depende de todo, ipodremos alguna vez conocer la causa de algo? La respuesta no parece sencilla.

\footnotetext{
${ }^{12}$ Actualmente, más que de teoría de sistemas se habla de análisis de Sistemas
} Complejos o, directamente, de Sistemas Emergentes.
Para Lewis-Gaddis, aunque la mayoría de los historiadores sabe instintivamente cómo responder a tal cuestión, lo normal es que se evite: «No preguntéis, no diremos nadarespondemos a menudo cuando nuestros estudiantes preguntan por la causación-. Limitaos a terminar la tesis. Cuando lo hayáis comprendido, os lo haremos saber» (2004: 126). Capra por su parte, admite que, puesto que todos los fenómenos están interconectados, para explicar cualquiera de ellos es preciso comprender todos los demás — lo cual obviamente resulta imposible- Con todo, lejos de considerarlo un inconveniente, Capra incorpora el obstáculo entre las cualidades del paradigma: «lo que convierte al planteamiento sistémico en una ciencia es el descubrimiento de que existe el 'conocimiento aproximado'. Esta percepción resulta crucial para la totalidad de la ciencia moderna. El viejo paradigma se basa en la creencia cartesiana de la certitud del conocimiento cientifico. En el nuevo paradigma se admite que todos los conceptos y teorías científicas son limitados y aproximados; la ciencia no puede facilitar una comprensión completa y definitiva» (1998: 60-61).

Nuestra perspectiva al respecto de la causalidad en el marco holístico es un poco la de M. Bloch cuando propone el ejemplo del hombre que cae por el precipicio y muere. Para que se produzca este trágico resultado, señala Bloch, tienen que darse muchas condiciones: un resbalón, un sendero al borde de un abismo, unos procesos geológicos que hayan generado la montaña, la acción de la fuerza de la gravedad, etc., y sin embargo, probablemente, cualquiera que fuera interrogado por el accidente contestaría con sencillez: «Un mal paso». Según Bloch, la razón de que todos tendamos a esta respuesta radica en que, ese antecedente particular —el del resbalón-, se diferenciaría de los otros por ser el último de una secuencia de hechos, siendo además el más excepcional en el orden general de las cosas.

Lewis-Gaddis, profundizando en el ejemplo de Bloch, advierte no obstante que la posición relativa dentro de una misma secuencia de hechos no es suficiente para determinar cuáles son relevantes, sugiriendo que aún habría que distinguir entre causación necesaria y causación suficiente. Para Gaddis, las condiciones presupuestas para el descrito accidente eran todas necesarias, salvo el resbalón. Éste era una causa suficiente pero carente de valor por sí sola: «Una causa suficiente depende de causas necesarias: por esa razón un mal paso en la montaña es más peligroso que uno en la llanura. Analizar el traspié sin especificar dónde se produce no tiene sentido. Las causas tienen siempre contextos, y para conocerlas debemos comprender éstos» (2004: 129-132).

Por nuestra parte, con el citado ejemplo pretendemos poner de manifiesto que, aunque el marco de análisis en 


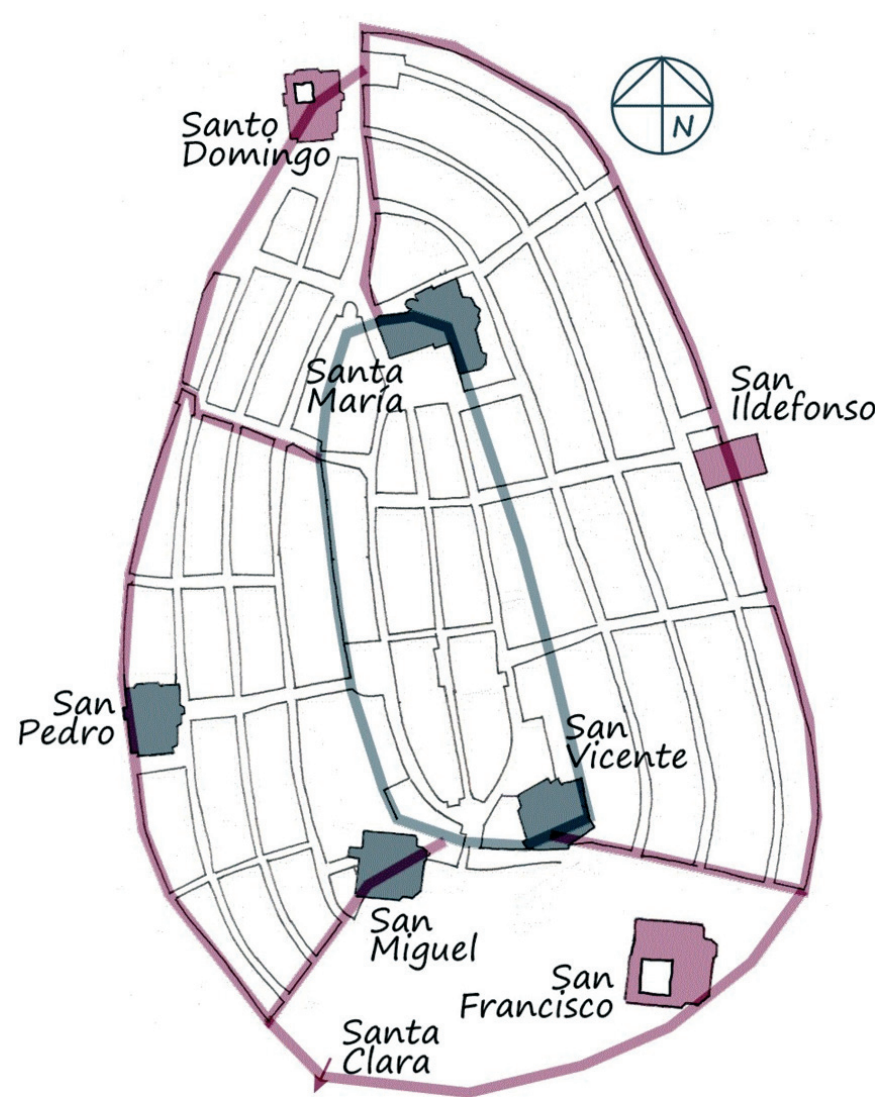

Fig. 4. Plano de Vitoria a finales del siglo XV. Destacando sobre el entramado de calles, el trazado de las murallas y los distintos templos (los elementos de color granate hoy están desaparecidos)

que nos reconocemos es esa visión holística o ecológica por la cual todo está conectado, sin embargo, nos hemos decantado por una vía determinada, primando unas variables y descartando otras a la hora de abordar el estudio del fenómeno urbano de Vitoria-Gasteiz ${ }^{13}$.

Con seguridad, múltiples han sido las causas necesarias que han provocado el enorme despliegue urbano de la sociedad actual pero sólo unas pocas causas suficientes han dado lugar a esto que hoy reconocemos específicamente como Vitoria-Gasteiz. Sin ánimo de descalificación; Vitoria-Gasteiz es como el cadáver del ejemplo de Bloch. Es el último suceso de la secuencia de hechos, o mejor dicho, su producto; en esta idea se basa nuestro criterio de selección de edificios a estudiar ${ }^{14}$. Al desarrollar nuestras investigaciones sobre Vitoria hemos procurado centrarnos en aque-

\footnotetext{
${ }^{13}$ "En el proceso de investigación, lo más importante es saber distinguir, de un cúmulo de hechos, aquellos que son accidentales y aquellos que son esenciales. De lo contrario, nuestra energía y nuestra atención se dispersa, en lugar de concentrarse» atribuido a Sherlock Holmes (Baldini, 1995: 50).

${ }^{14}$ "No hay nada menos real que el realismo. Los detalles confunden. Sólo mediante la selección, eliminación y el énfasis podemos llegar al verdadero significado de las cosas». G. O’Keeffe (Solé, 2009: 15).
}

llos elementos aún presentes en la trama urbana que sin embargo tienen una gran proyección hacia el pasado. Así pues, guiándonos por una suerte de principio de disminución de la pertinencia —utilizando la terminología de Lewis-Gaddis - hemos optado por aquéllos que han estado presentes transversalmente a lo largo de, prácticamente, toda la historia de la ciudad. Hablamos en esencia del sistema amurallado y del sistema templario de nuestra ciudad, a saber, el primitivo recinto mural de Villasuso y sus distintas ampliaciones plenomedievales, las iglesias de Santa María, San Vicente, San Miguel, San Pedro y los Conventos de San Francisco, Santo Domingo y Santa Clara (Fig. 4).

Nuestra elección de murallas y templos como principales objetos de estudio no deriva por lo tanto de consideraciones como la monumentalidad, ni siquiera del gran interés que despierta en nosotros la historia de las elites, de la Iglesia o la poliorcética medieval. Lo que deseábamos enfatizar era precisamente su carácter de, por así decir, testigos aún vivos del devenir histórico de Vitoria.

En ellos, lo interesante no es tanto que su arquitectura actual responda esencialmente a su estructuración originaria, medieval o moderna, sino sobre todo que ésta soporta y contiene todas las evoluciones estructurales posteriores hasta nuestros días. A través de las murallas podemos remontarnos selectivamente hasta la decimoprimera centuria, pero en ellas también podemos rastrear la diacronía, el devenir histórico de la ciudad, siglo a siglo hasta la actualidad. Estas murallas, al igual que los templos son -directamente, sin intermediarios, e incluso antes de estudio arqueológico alguno- elementos de la cultura material de tiempos pasados que tienen la cualidad de convivir aún hoy con nosotros (Fig. 5), o dicho de otro modo, son parte de nuestra cultura material moderna puesto que forman parte del paisaje cotidiano con el que interactuamos.

Como señala F. Capra, en cualquier punto del camino, la estructura del organismo vivo (la ciudad, las murallas, los templos y otros edificios de algún modo son seres vivos ${ }^{15}$ ) es el historial de sus cambios estructurales anteriores y, por lo tanto, de interacciones pasadas. Esta ontogenia es la que hace que la estructura de un edificio aún vivo sea como un diario, como una biblioteca ("la ciudad no dice su pasado, lo contiene como las líneas de una mano, escrito en los ángulos de las calles»).

\footnotetext{
15 "La ciudad presenta un metabolismo similar al de un organismo vivo. La ciudad importa materia y energía, en forma de alimentos, materiales de construcción, energía de distintos tipos, agua e información, y exporta residuos sólidos, aguas residuales, productos, información, etc.» (Saura i Carulla, 2003: 118).
} 


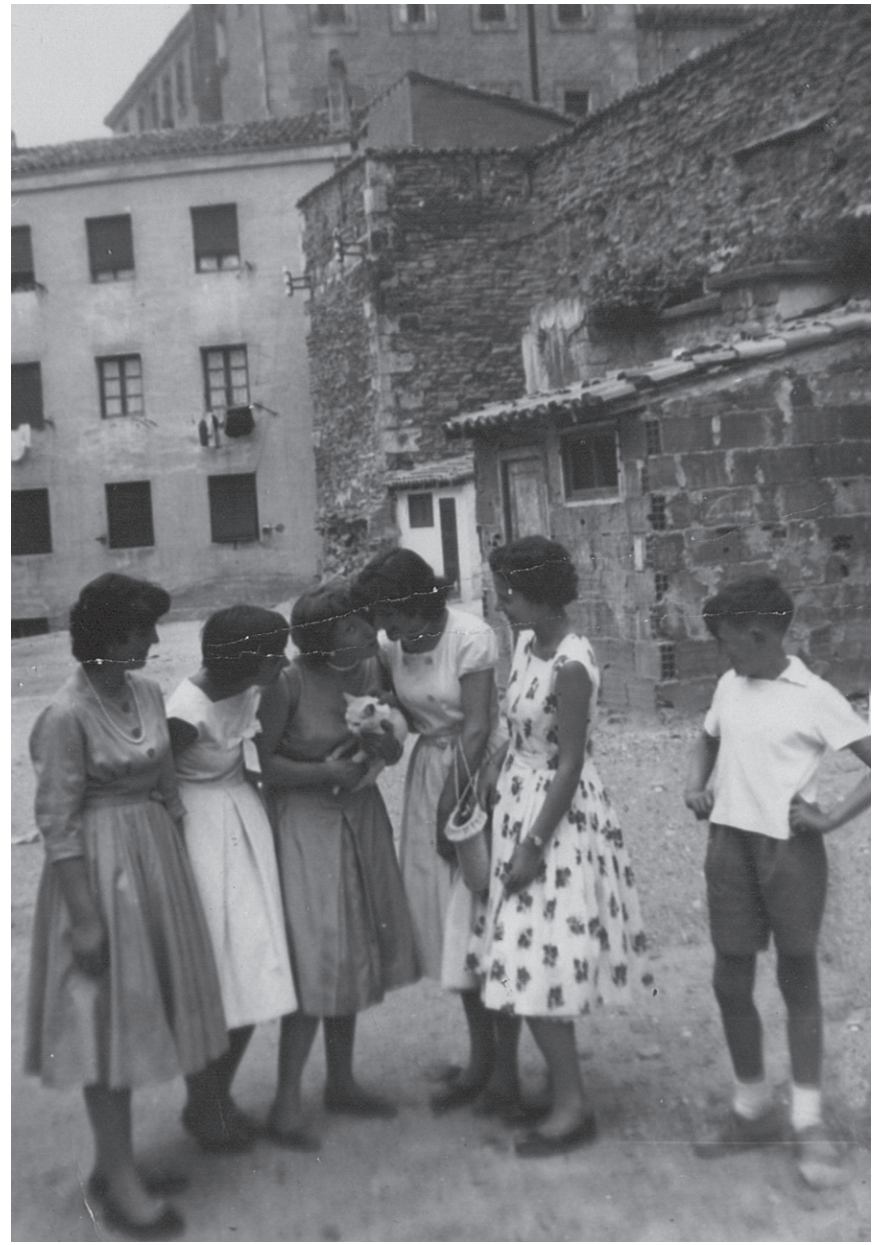

Fig. 5. Años 50. La muralla ha estado ahí desde el siglo xı. Agazapada, contemplando desde un segundo plano la vida que transcurría ante ella. En todo este tiempo, sus muros no han dejado de acumular información; el desmoche de sus torres, o esos cobertizos que vemos adosados en la imagen son muestra de ello. Foto: Begoña Anguita

\subsection{Propiedades emergentes de los sistemas complejos}

Según la visión sistémica, las propiedades esenciales de un sistema son propiedades del todo que ninguna de las partes posee por separado; emergen de las interacciones y relaciones entre las partes (Fig. 6) ${ }^{16}$. Esas partes son destruidas cuando el sistema es diseccionado, ya sea física o teóricamente, en elementos aislados (Capra, 1998: 48).

Poner el acento en las cualidades permanentemente emergentes del espacio urbano implica advertir que éste no puede patrimonializarse como cosa ni como enclave. Su-

\footnotetext{
${ }^{16}$ K. Kelly señala: "El espiritu de la colmena, el comportamiento de la economía, el razonamiento de un superordenador y la vida en mi están distribuidos según una multitud de unidades más pequeñas (las cuales a su vez pueden estar repartidas en otras unidades). Cuando la suma de las partes puede tener un sentido conjunto, entonces ese ser extra (ese algo de la nada) se distribuye entre las partes. Siempre que encontramos algo de la nada, vemos que surge de un campo de muchas piezas más pequeñas que interactúan» (2002: 138).
}

pone asumir que no es producto de una única decisión sino de una constelación de ellas, que no es sólo el resultado de la voluntad de una persona sino más bien de la acción combinada de toda una colectividad.

En este sentido, nos parece muy oportuna la advertencia de M. Delgado, cuando dice que la ciudad «ni es una cosa —un objeto cristalizado-, ni un enclave —un fragmento de territorio dotado de límites-» (2007: 12). Coincidimos con Delgado en que, efectivamente, la ciudad no es tanto un objeto cristalizado como un objeto en perpetua cristalización, y que tampoco es un enclave perfectamente delimitado o localizado sino más bien una "mancha» sobre el territorio, de bordes más o menos difusos. Ahora bien, también pensamos que existen ciertos elementos dentro del sistema urbano de Vitoria-Gasteiz que al haber mantenido la misma estructura esencial desde sus orígenes hasta la actualidad, nos permiten hablar de un cierto patrón de organización quizá no completamente cristalizado, pero sí muy consolidado (se trata de más de doce siglos de historia). El trazado de calles del casco medieval es una clara muestra de ello, también lo es la estructura de las murallas y, cómo no, la arquitectura de las iglesias.

Estos tres tipos de elementos son, a nuestro juicio, la expresión arquitectónica que delata la consolidación de algunas de las principales propiedades emergentes de un sistema urbano como Vitoria-Gasteiz; la presencia de estos edificios es una prueba (si bien no la «única») de que, como decíamos, ciertas propiedades del sistema son propiedades del todo que ninguna de las partes posee por separado. Mucho más que el abigarramiento del caserío, la existencia de una iglesia denota un alto grado de cohesión de la colectividad, ésta será además un instrumento imprescindible para la reproducción y perpetuación efectiva de una específica geometría social, en este caso concreto, la geometría social de la comunidad de creyentes de la localidad donde se enclava el edificio. La muralla también es una expresión de esa propiedad emergente del sistema urbano si la tomamos por ejemplo como instrumento, del que la colectividad se sirve para definir con claridad su identidad (los de dentro frente a los de fuera); y, en fin por supuesto, la calle, que no es — no puede ser- sino la calle de la comunidad. Suscribimos las palabras de R. Wright: "Así como las diversas estructuras de un organismo lo defienden de las fuerzas entrópicas, algunas estructuras sociales impiden que la sociedad se desintegre. Esto es rigurosamente cierto en el caso de las murallas de Jericó, que tal vez sea el monumento vivo a la productividad agrícola más antiguo que se conoce. Incluso los templos de jefatura —al margen de si eran instrumentos para oprimir y controlar a las masas o para 


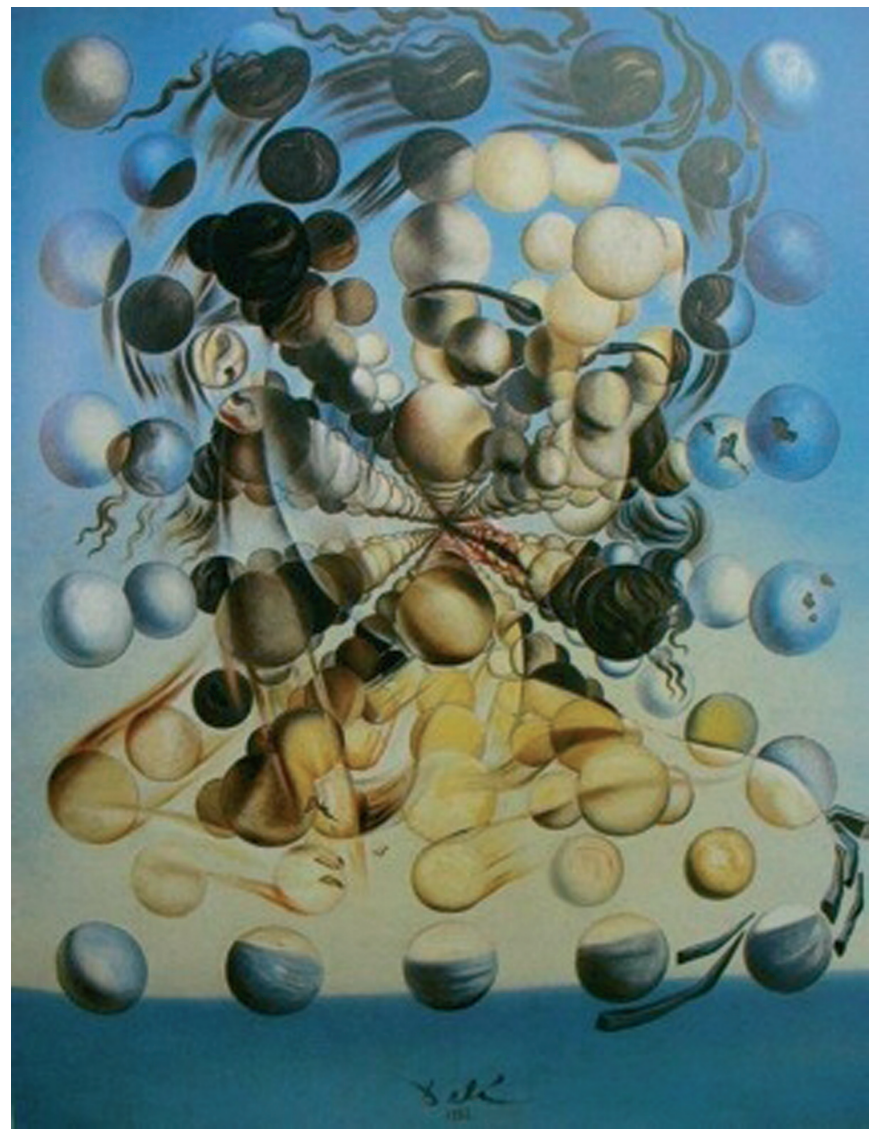

Fig. 6. Propiedades emergentes. Según la visión sistémica, las propiedades esenciales de un sistema son propiedades del todo que ninguna de las partes posee por separado; emergen de las interacciones y relaciones entre las partes. Así, el rostro femenino que percibimos en la imagen, emerge del conjunto de esferas que la componen. Estas esferas, tomadas por separado, no difieren mucho unas de otras, ninguna posee un rasgo característico que prefigure que con ellas se puede esbozar un rostro y sin embargo, a la vista de esta pintura, nadie diría que lo que ve sólo es un montón de esferas. S. Dalí, Galatea en las esferas

coordinarlas pacificamente - fueron en cierto modo integradores, ponian orden en una sociedad amplia, daban cohesión orgánica» (2005: 262).

\subsection{RECURRENCIA ESCALAR}

En su obra "El mapa fantasma», S. Johnson hace referencia a un concepto que creemos que describe otra de las características del enfoque sistémico. Hablamos del pensamiento confluyente, un término acuñado por W. Whewell (filósofo inglés de finales del XIX) que al reflexionar sobre los métodos de la ciencia de su tiempo sugería: " $L a$ confluencia de las inducciones tiene lugar cuando la inducción obtenida de un grupo de hechos coincide con una inducción obtenida de un grupo diferente. Asi pues, la confluencia sirve para probar la verdad de la teoría en la que sucede» (Johnson, 2008: 64). Whewell recogía en este enunciado una idea que sin embargo no parece haber arraigado hasta la segunda mitad del siglo XX en el seno de las corrientes de pensamiento estructuralistas.

Quizá sean los ecos del pensamiento del filósofo británico, los que - pasados por dicho tamiz estructuralista- resuenan tras la 'recurrencia estructural' de que nos habla F. Criado. Este autor propone dentro de su método interpretativo, una ineludible primera fase que tendría como objeto comprobar la coherencia e integridad de una interpretación. Para ello, habría que examinar «si la regularidad o estructura descrita por la hipótesis interpretativa reaparece en otras escalas, ámbitos o códigos de la misma formación cultural analizada» (2006: 249-250). Si bien Criado no otorga a esta 'regularidad estructural' un valor decisivo ("pues lo único que se contrasta es si la hipótesis es correcta viendo si la regularidad que propone se documenta en otros casos»), para nuestros fines de análisis del hecho urbano el concepto de 'recurrencia estructural' tiene una gran importancia, ya no solo por su valor como verificador de hipótesis, sino también porque considera el espacio como un sistema de saber intrínseco a cada cultura ${ }^{17}$.

En fin, adoptando la terminología de Whewell para intentar recoger en un término los matices de nuestro enfoque, podría decirse que también nosotros abordamos el análisis del hecho urbano de un modo confluyente $e^{18}$; primero, porque rastreamos la recurrencia, los patrones de comportamiento semejantes a distintas escalas y, segundo, porque tratamos de comprobar si la motivación de un hecho arquitectónico o urbanístico se encuentra a una escala distinta a la que se manifiestan los efectos (Fig. 7) ${ }^{19}$.

La decisión de emplear una piedra de cierta geología para erigir un muro, o la elección de una determinada técnica constructiva, la «inoportuna» localización de una antigua fuente o la preexistencia de una vereda, han sido microrrazones que, a menudo, nos han servido para explicar satisfactoriamente el por qué de la aparente anomalía

${ }^{17}$ Criado señala: «los códigos expresivos de una cultura son, por fuerza, limitados, de tal modo que si uno tiene que ordenar su entorno posiblemente lo hará con categorías transferidas de un ámbito próximo y, con seguridad, aplicando un único y mismo concepto de espacio, que es el que el sistema de saber en el que está embebido le suministra” (2006: 250).

${ }^{18} \mathrm{Si}$ nos ceñimos al marco conceptual arquitectónico-urbanístico, a nuestro juicio, el pensamiento confluyente encuentra su mejor paralelo en las escalas de dimensiones concurrentes de Caniggia y Maffei, autores que no dudan en resaltar que cada escala de dimensiones constituye un momento de comprensión "gradualmente aumentada" fundamental en la comprensión de la ciudad como sistema urbano (1995: 81). En cualquier caso, la cuestión de las escalas en la articulación de sistemas urbanos siguen preocupando en el ámbito disciplinar de la arquitectura, ya desde un nuevo enfoque, como se puede apreciar en Saura i Carulla (2003: 28-30).

19 "Nuestra comprensión del mundo está formada por innumerables capas. Cada una merece ser explorada, siempre que no olvidemos que es una entre muchas" de E. Chargaff (Solé, 2009: 15). 
en la configuración de algunas de esas macrorrespuestas urbanísticas que son las murallas, las calles, las plazas o, por qué no, los propios templos.

No creo que esta idea pueda sintetizarse mejor que lo hizo Thomas Schelling en Micromotives and macrobehavior (1978) —un título ya de por sí expresivo—, pero en esta obra se obtiene la inquietante sensación de que los objetos cobran vida, que son ellos $-\mathrm{y}$ no tanto los individuos que los usan - los que mueven el mundo. Evidentemente, eso no es así. Individual o colectivamente es el ser humano quien genera el movimiento, quien promueve un escenario de constante interacción, quien construye un edificio o traza una carretera, lo que sucede es que, precisamente su papel demiúrgico, su omnipresencia, provoca que muchas veces su actividad se de por sobreentendida en ciertos análisis. En este sentido, preferimos discursos como el de M. Harris, donde apreciamos que el individuo y su sistema de creencias están en el centro del mismo, como microrrazones capaces de generar dinámicos comportamientos de masa que -aunque estén en constante interacción con el ecosistema- no siempre responden a variables estrictamente ecológicas: "Ahora es el momento adecuado para rechazar la afirmación que sostiene que todas las prácticas alimenticias tienen explicaciones ecológicas. Los tabuies cumplen también funciones sociales, como ayudar a la gente a considerarse una comunidad distintiva» (2006: 48).

Este es quizá el momento de añadir que un aspecto fundamental en nuestro análisis (con implicaciones a distintas escalas), lo constituye la semantización del espacio, o más concretamente, su sacralización. La muralla, los edificios templarios y por supuesto la ciudad, son sistemas complejos construidos mental y físicamente a partir de una forma de comprensión del medio, del paisaje. Todos ellos, son sistemas emergentes en tanto que cristalizaciones de una geometría social en permanente redefinición, el producto de una interacción diaria de múltiples individuos que no se reduce a lo material, sino que también depende del mundo de las ideas.

A continuación hacemos una pequeña síntesis del espectro escalar (un total de seis escalas de dimensiones concurrentes) en que nos hemos movido para estudiar el fenómeno urbano de Vitoria, partiendo desde lo micro, para, poco a poco, llegar a lo macro.

a) Materiales. La menor de las escalas a la que hemos recurrido es la de la distribución de los distintos tipos líticos empleados en la construcción del tejido urbano. El conocimiento a esta escala ha resultado fundamental para entender, en otras superiores, el modo en que se ha

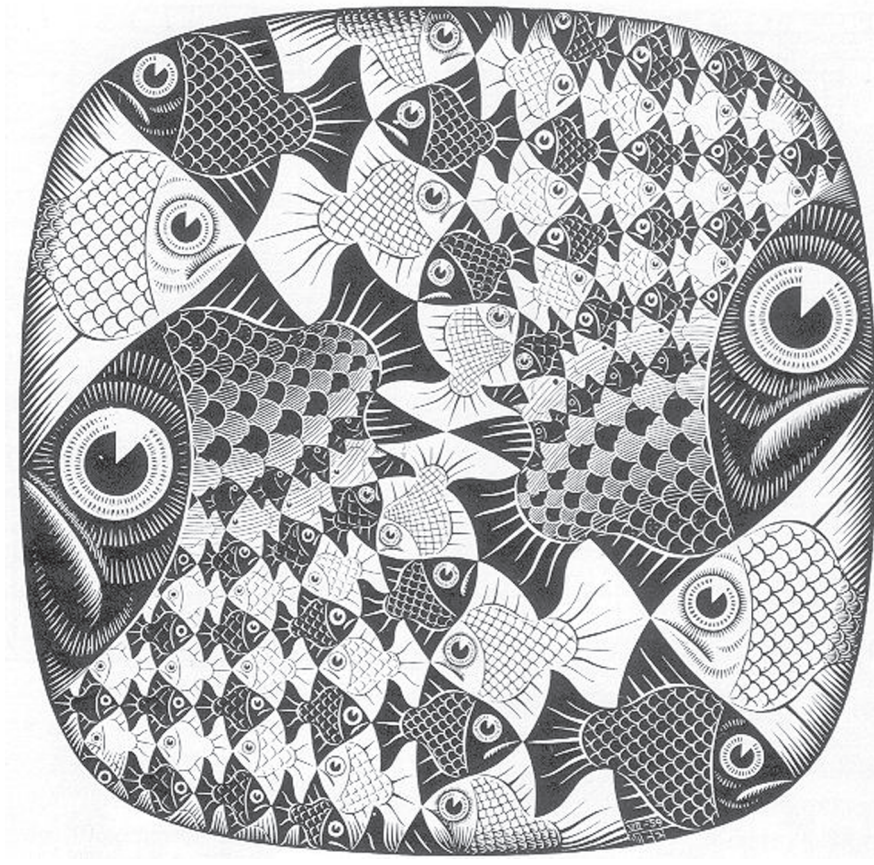

Fig. 7. Dimensionalidad concurrente. Obsérvese el modo en que se estructura la ilustración. Peces compuestos de peces, peces de distintos tamaños cuyos contornos encajan sin embargo con coherencia. Ángulos y puntos de confluencia, múltiples escalas que conviven en armonía, esta es una forma de plasmar gráficamente la confluencia. (Ernst, 1994: 34)

articulado el ciclo productivo de la piedra en Vitoria y su entorno, la localización de las canteras, las rutas de acceso a la villa, el valor económico o los costes de producción, etc. Ha sido muy interesante por ejemplo comprobar cómo hasta bien entrado el siglo XIII el sistema lítico en que se basaban todas las obras de la villa estaba compuesto casi en exclusiva por la calcarenita. Entre los siglos XIII y XVI en ese sistema se consolidó la presencia de la lumaquela, y sólo a partir del XVII nos encontramos ante un sistema ternario de calcarenita, lumaquela y arenisca. Dada la posición de las respectivas canteras, el recurso a uno u otro tipo de material nos ha dado una buena medida de la evolución del hinterland vitoriano.

b) Técnica constructiva. El material lítico, sustancia primordial en la estructura de los edificios que hemos estudiado, fue empleado según distintos criterios. Por sus características, margas y calcarenitas casi siempre han sido empleadas como mampostería común (en algunos casos como sillarejo), mientras que la lumaquela se ha reservado para la sillería y los detalles escultóricos más complejos. Además, según los requerimientos de cada edificación, la técnica constructiva, es decir, el modo de disponer los bloques pétreos para formar los muros, ha cambiado. Aparejos completamente en mampostería o completamen- 


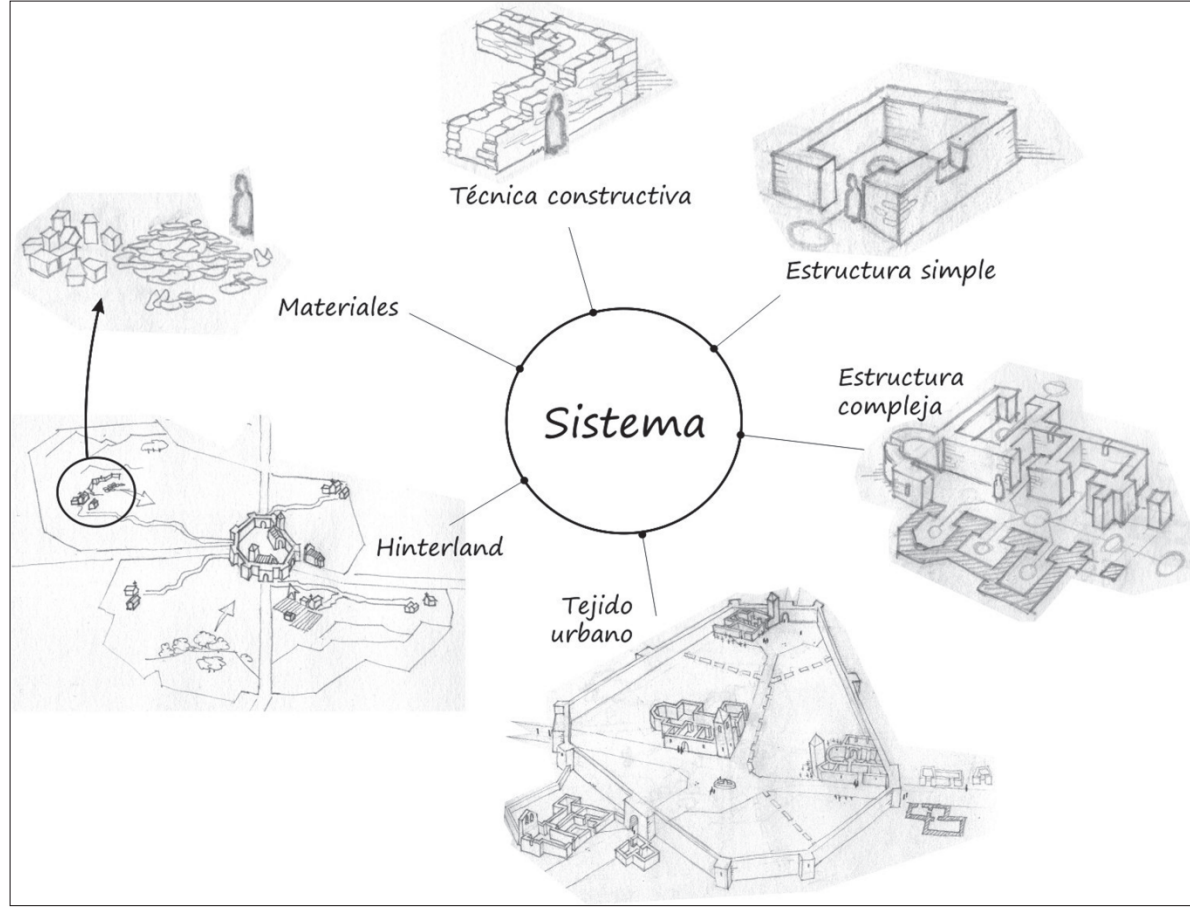

Fig. 8. Escalaridad concurrente. Tal como pretendemos enfocar su estudio, el sistema urbano de VitoriaGasteiz se despliega en múltiples escalas. Todas ellas coexisten coherentemente, encajando unas sobre otras como las piezas de una muñeca rusa, o como en la ilustración «Peces y escamas» de Escher. En el enfoque confluyente, la respuesta a ciertos problemas que se plantean a determinada escala, a menudo se encuentran en otra distinta te en sillería, aparejos mixtos de mampostería en paramentos con esquinales de sillería, han sido los más habituales; otros sin embargo han resultado mucho más específicos, como por ejemplo el aparejo en espiga de pez (empleado de forma sistemática en las cimentaciones de la muralla). Profundizar en esta escala se ha revelado como una de las claves para discernir las distintas fases de la evolución histórico-constructiva de las estructuras más complejas; por ejemplo, para distinguir las etapas de edificación de las ampliaciones de la muralla (que son mucho menos unitarias de lo que en un principio se pensaba) o, de nuevo, para inferir importantes transformaciones en la articulación del propio ciclo productivo de la piedra.

c) Articulación de estructuras simples. El término estructura simple es nuestra adaptación del concepto elementary building de Hillier y Hanson (2001: 176), con aportes de la noción de lugar primitivo de S. Unwin (2003: 53-73). Los dos primeros entienden el edificio elemental como la celda cerrada, a saber, el espacio delimitado por una solución de continuidad, una barrera, que lo escinde del resto, si bien manteniendo un cierto grado de permeabilidad (por medio de puertas, ventanas o dispositivos similares) con una celda abierta contigua (una celda abierta que puede ser el espacio exterior directamente) ${ }^{20}$. Basándo-

${ }^{20}$ Es posible sin embargo que la cerrazón de dicha celda sea tan escasa, tan poco evidente físicamente - como por ejemplo en un tenderete de comercio ambu- nos pues en estas ideas, en nuestro trabajo concebimos la estructura simple, como un habitáculo sin subdivisiones físicas categóricas ${ }^{21}$; puede ser la cabaña de alguno de los primitivos pobladores de la Gasteiz del siglo VIII, la nave de una pequeña ermita o de una gran parroquia, el patio de un claustro, el espacio de una sacristía o de una capilla, el hueco definido por los muros de una torre de vigilancia,

lante- que visualmente pueda dar la apariencia de una celda abierta. En esos casos, la clave para distinguir la celda cerrada de la celda abierta consistiría en tener en cuenta que el espacio de aquélla está reservado para el habitante —en el caso de la tienda, sería el propio comerciante-, mientras que la celda abierta (el espacio exterior) es el espacio del visitante, aquel individuo esencialmente ajeno a la celda cerrada - en nuestro ejemplo, la persona situada al otro lado del mostrador-: "La celda cerrada es el dominio del habitante, sólo, mientras que la celda abierta es el lugar del interfaz habitante-visitante. Este edificio elemental no concierne en exclusiva a la antigüedad o a las sociedades primitivas. Se pueden encontrar ejemplos aún hoy día. Por ejemplo, la tradicional tienda — que durante el día dispone fuera sus productos en el espacio en frente de la celda cerrada, haciendo que el espacio interior sea lo más continuo posible con respecto al exterior- está explotando el potencial básico de esta estructura. Por la noche, todas las mercancías se colocan dentro de la celda cerrada y la permeabilidad es completa». (Hillier y Hanson, 2001: 176-177).

${ }^{21}$ En la propuesta de Hillier y Hanson un espacio sin subdivisiones físicas evidentes puede estar fuertemente estructurado en base a otros criterios derivados de la propia codificación social. Así, los distintos ángulos de una habitación pueden tener distinto significado y estar reservados a distintos usos, o a cierto tipo de personas (2001: 177-180). Sin dejar de tomar en consideración esta circunstancia, por una mera cuestión práctica hemos preferido no entrar en el análisis de estos esquemas de ocupación del espacio, salvo en aquellas ocasiones en que nos ha parecido que este tipo de análisis era absolutamente imprescindible para comprender el edificio como espacio de sociabilidad; por ejemplo, en el caso de la nave de una iglesia donde es importante distinguir, altares o deambulatorios de capillas, intercolumnios o sotocoros, áreas no necesariamente bien delimitadas, pero muchas veces reservadas para uso restringido de unos pocos. 
etc. A una escala inferior, todos estos espacios han sido confeccionados por medio de unos materiales y unas técnicas constructivas determinadas (escalas a y b respectivamente); en una escala superior (d), estas estructuras simples, sirven para conformar otras más complejas; las naves, las capillas y las sacristías hacen la iglesia, las torres hacen la muralla, el conjunto de las viviendas dispuestas a los lados del camino hacen la calle, y así sucesivamente. El estudio de esta escala nos ha servido de puente para conocer de cerca los usos específicos del espacio, la relación entre la geometría social y la cristalización material de las interacciones humanas, en definitiva, como han pretendido Hillier y Hanson, nos han permitido profundizar en la lógica social del espacio.

d) Articulación de estructuras complejas. Siguiendo con el enfoque propuesto por los citados autores anglosajones, a una escala mayor, denominaremos estructuras complejas aquellas que entendemos como el producto de la adición de sucesivas estructuras simples (elementary buildings): "Con el paso del tiempo, los lugares que usa la gente se hacen más variados y sofisticados, a la vez que sus interrelaciones ganan en complejidad» (Unwin, 2003: 53). No obstante, es necesario insistir que la distinción entre estructuras simples y complejas no deja de ser un artificio que sólo pretende facilitar el trabajo de análisis; no es tanto una división basada en las características inherentes al objeto de estudio, como una clasificación que, creemos, permite al observador aproximarse a las motivaciones del hecho construido de un modo ordenado y satisfactorio. Así, en el caso de las estructuras simples, consideraremos cualquier espacio contiguo a una celda cerrada como exterior -es decir, como espacio ajeno_-; esto se percibe fácilmente en el caso del espacio interior de una cabaña frente a la pradera en la que se enclava, pero también describe el caso de la capilla de un templo cuando la analizamos de forma aislada (en esta ocasión, es el propio templo el que puede considerase exterior a la capilla). En cambio, cuando hablamos de estructuras complejas, hablamos, por así decir, de un encadenamiento de espacios: la cabaña con respecto a la pradera difícilmente podría ser considerada como una estructura compleja, salvo si por ejemplo esta cabaña se rodeara de un cercado; ahí, ya se produciría un mínimo encadenamiento de espacios (antes de entrar en la cabaña es necesario entrar en el cercado). En el ejemplo de la capilla, el encadenamiento se produce con sólo cambiar de escala de análisis, porque una capilla habitualmente sólo se comunica con la nave del templo del que forma parte, de modo que, para acceder a ella lo normal es que primero se haya entrado en el templo. Esta cadena podría ampliarse sucesivamente si el templo, por ejemplo, se encontrase dentro de un convento. Esta es la escala de articulación compleja donde se perciben más coherentemente la mayoría de los edificios tratados en nuestras investigaciones sobre Vitoria: nos referimos a las iglesias (Santa María, San Vicente, San Miguel, San Pedro y San Ildefonso) y a los conventos (Santo Domingo, San Francisco y Santa Clara).

e) Articulación del tejido urbano. Nuestra definición de esta escala de estudio es, en su mayor parte, deudora de las reflexiones de $\mathrm{K}$. Lynch sobre el fenómeno urbano - particularmente de sus conceptos de senda, borde, barrio, nodo y mojón (2004: 62)—, si bien la noción de tejido urbano y de aglomeración en Caniggia y Maffei (1995: 80), nos han influido de forma considerable. Como cabe deducir por lo dicho en las escalas inferiores, en nuestro esquema de análisis el tejido urbano es el resultado de la acumulación, o mejor, de la aglomeración, de un conjunto de estructuras complejas; las iglesias, los conventos, las viviendas, los patios o los solares de huertas, son ejemplo de algunas de éstas. De la interactuación de todos estos elementos, emerge la urbe como esa propiedad del todo que los componentes no poseen pos sí solos: "La forma urbana es cumulativa (...) pero es algo más y algo distinto que la sola acumulación» (Lefevbre, 1972: 125). El carácter emergente de la ciudad se percibe en las consecuencias físicas de la aglomeración de las distintas entidades; las calles (sendas, según la terminología de Lynch), las murallas (bordes), las circunscripciones parroquiales, los arrabales o la judería (barrios), las plazas o cementerios (nodos) y las propias iglesias, en cuanto que referencias físicas dentro del entramado urbano (mojones). En esta escala es donde se visibiliza en su globalidad el patrón de organización del sistema urbano de Vitoria-Gasteiz; los distintos edificios que lo componen pasan gradualmente a un segundo o tercer plano (sobre todo la arquitectura residencial), si bien aquéllos que expresan con mayor determinación la presencia de una comunidad, es decir, que constituyen polos de congregación ${ }^{22}$, despuntan como ejes articuladores del urbanismo; es el caso de las murallas y de los propios templos (también de los mercados por ejemplo). En lo urbanístico, las murallas compactan, dan coherencia al tejido urbano; en lo social, lo definen, trazan la línea que distingue a los que viven dentro $-\mathrm{y}$ por lo tanto son

\footnotetext{
22 "Los signos de lo urbano son los signos de la congregación: las cosas que permiten la congregación (la calle y el suelo de la calle, piedra, asfalto, acera, etc.) y las estipulaciones de la congregación (asientos, luces, etc.)" (Lefebvre, 1972: 124).
} 


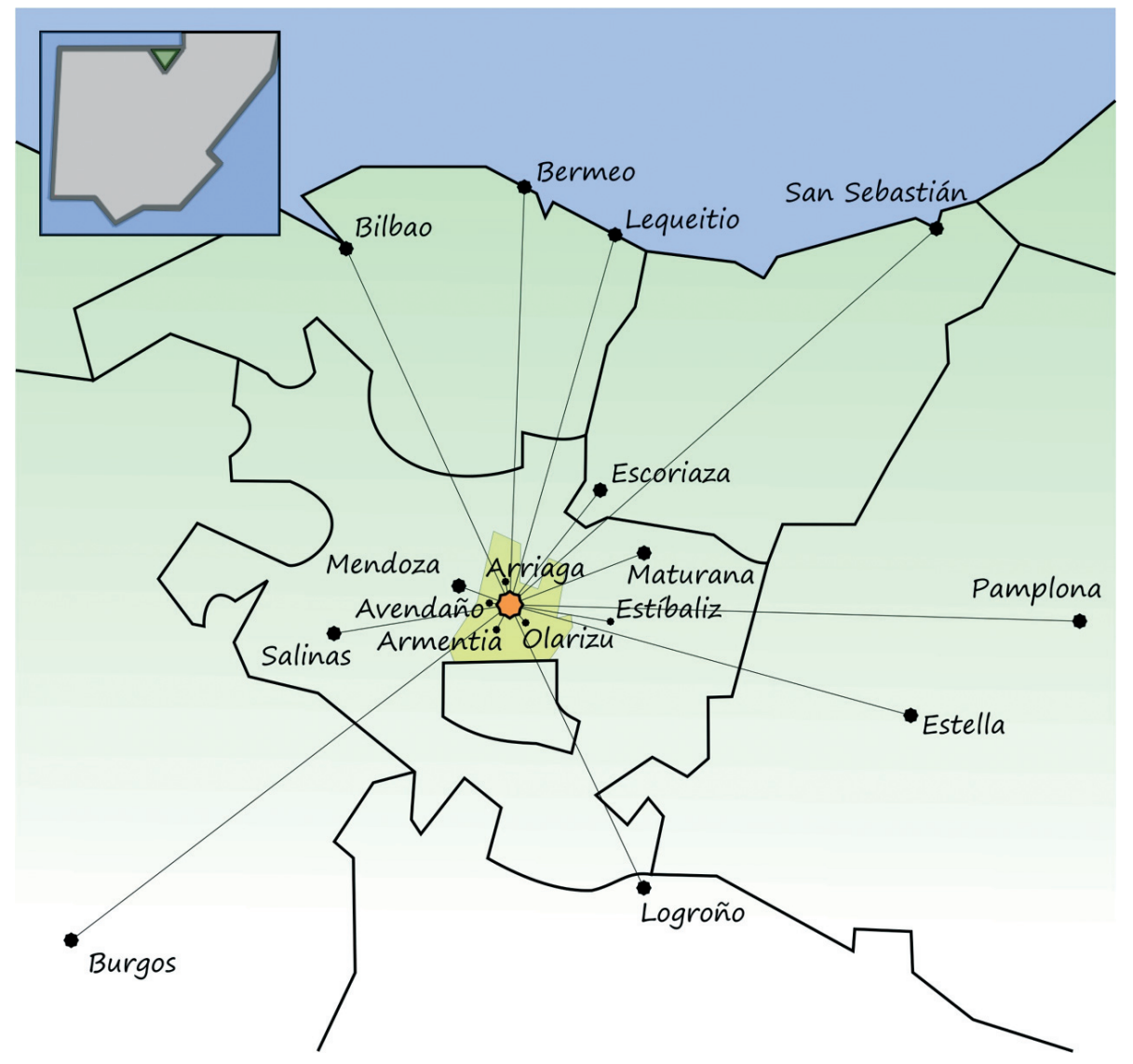

Fig. 9. La red local del hinterland vitoriano. Destacado con mancha amarilla, la extensión del primitivo término municipal de Vitoria-Gasteiz
Vitoria- de los que viven fuera. Los templos también contribuyen a la construcción de una identidad común, en primer lugar porque en todos ellos se reproduce un mismo sistema de creencias, en segundo lugar porque, de algún modo, la iglesia es entendida como la casa de todos, la casa de casas; todos los vecinos de la ciudad pertenecen a alguna parroquia ${ }^{23}$, todos los antepasados de la comunidad se encuentran sepultos en el cementerio parroquial (que durante gran parte de la Edad Media estuvo dentro del propio recinto templario).

f) Articulación del hinterland. El sistema urbano Vitoria-Gasteiz no es un fenómeno aislado. Como sistema termodinámico abierto, la ciudad depende por completo del medio en el que evoluciona; de él obtiene prácticamente todo, alimentos, materias primas, productos manufacturados de toda índole, efectivos demográficos, formas de organización, sistemas tecnológicos, simbólicos, sistemas de creencias, políticos, constructivos, etc. ${ }^{24}$ Aunque apa-

${ }^{23}$ Evidentemente, quizá con la salvedad de aquéllos que profesan otras religiones; judíos, y en mucha menor medida musulmanes.

${ }^{24}$ Según Fernández-Galiano: "La inexcusable dependencia entre organismo y medio es, en efecto, manifestación del mismo fenómeno que causa la heteronomía de lo rentemente pudiera parecer que las murallas hacen de la ciudad una especie de gueto, es evidente que VitoriaGasteiz ha vivido a lo largo de su historia de la apertura, nutriéndose de los flujos de materia y energía procedentes del exterior, si bien, por supuesto, todo lo que ha llegado ha sido después reelaborado, sintetizado y asimilado, para construir poco a poco su singularidad. Dentro de una concepción reticular del sistema urbano, Vitoria sólo es un nodo entre miles, como es evidente, sus relaciones han sido históricamente más fluidas con los centros geográficamente más próximos, y por ello, en nuestras investigaciones nos hemos referido con mayor frecuencia a ciudades como Pamplona, San Sebastián, Burgos, Bilbao, Logroño, etc.

A esta escala, resulta por ejemplo muy estimulante la sola reflexión sobre el origen de los apellidos de las familias que detentan el poder en Vitoria a finales de la Edad Media; estos linajes, mecenas de las grandes operaciones constructivas en los templos vitorianos, nos remiten a poblaciones que sin duda hay que incluir en la red de

construido. La autonomía es, como se sabe, sólo característica de la simplicidad: todo lo complejo es heterónomo, o si se prefiere, 'interdependiente'. Una granja necesita de sus tierras de labor; una ciudad, de su 'hinterland' como los innumerables asedios de la historia bélica de la humanidad se han ocupado de subrayar» (1991: 93). 
centros mejor conectados con Gasteiz; Lequeitio, Estella, Bermeo, pero también — más cerca- Maturana, Escoriaza, Mendoza, Salinas, etc. (Fig. 9).

Ahora bien, el espacio que más hemos, por así decir, «trillado», ha sido el de la Llanada alavesa occidental, el área que más directamente ha co-evolucionado con Gasteiz (en una suerte de relación simbiótica) hasta incluso fundirse con ella. Hablamos de aquellas localidades, inmediatas, que en algunos casos acabarían formando parte incluso de su término municipal; desde Adurza hasta Arriaga, desde Subijana a Matauco. De hecho, macroescalarmente, no podemos sino constatar la profunda relación existente entre el crecimiento del término municipal de Vitoria entre los años 1258 y 1286 y, en la microescala, la imperiosa necesidad de la ciudad para asegurarse el suministro de piedra con que sustanciar su estructura urbana (la mayoría de las localidades que históricamente han abastecido de piedra a Gasteiz entraron a formar parte del municipio precisamente en 1258).

Por otro lado, resulta interesante reconocer que uno de los «flashes» iniciales que nos impulsaron a aplicar el enfoque sistémico al estudio de Vitoria, fue un mapa que se nos venía en mente sólo con repasar algunas de las celebraciones festivas más importantes de la ciudad y comprobar cómo mediante distintas romerías, Vitoria, o los vitorianos, persisten (o persistían, porque algunas ya no tienen lugar) en ejercitar su memoria, trazando anualmente diversas rutas que parecen funcionar como una red de anclajes físico/psicológicos que unen el núcleo de la urbe con ciertas localidades del entorno inmediato imprescindibles para la comprensión de su propia historia ${ }^{25}$, a saber, Armentia en San Prudencio, Avendaño en la Ascensión, Arriaga en San Juan, Estíbaliz el primero de Mayo y Olarizu el primer lunes después de la Virgen de Septiembre. Dibujados sobre el plano los respectivos recorridos procesionales, la ciudad situada al centro adquiere el aspecto de un octópodo que extiende sus tentáculos como intentando aferrar su propia memoria. Esta visión podría servir como síntesis gráfica de nuestra concepción de Vitoria-Gasteiz al centro de su hinterland (Fig. 9).

El hinterland cierra el elenco de las escalas consideradas en nuestras investigaciones sobre Vitoria, pero antes de finalizar con el epígrafe desearíamos hacer una observación más. Probablemente el lector haya percibido cierta similitud estructural entre la subdivisión que proponemos y

\footnotetext{
${ }^{25}$ Hasta bien entrado el siglo XIX y a modo de recordatorio, se siguió practicando la costumbre -no exclusiva de Vitoria- de visitar en procesión aquellas parroquias desaparecías adscritas al término de una cierta población.
}

otras sistematizaciones bien conocidas en Arqueología; la analítica de G. P. Brogiolo (1988, habitualmente aplicada en Arqueología de la Arquitectura y compuesta de menor a mayor por; Unidad Estratigráfica Mural, Elemento Arquitectónico, Estructura Horizontal, Unidad Funcional, Alzado Particular, Alzado General, Cuerpo de Fábrica y, finalmente, Complejo Arquitectónico), o la sintética de A. Carandini (1996, Unidad Estratigráfica, Actividad, Grupo de Actividades y Períodos). El parecido no es casual, primero porque ambas sistematizaciones han sido referencia fundamental para el conjunto de la arqueología moderna y, cómo no, para nosotros; segundo, porque ambas responden al aserto fundamental de todo enfoque sistémico: «los objetos en sí mismos son redes de relaciones inmersas en redes mayores» (Capra, 1998: 57). Sin embargo, ninguna de ellas se plantea un horizonte inferior a la Unidad Estratigráfica, ni ninguno superior al edificio o al yacimiento concreto. Es por ello que, de algún modo podría considerarse que ambas quedarían englobadas entre nuestras escalas 'b' y 'd' (Técnica constructiva y Articulación de Estructuras Complejas).

El nivel de comprensión 'e' resulta más difícil de alcanzar, si bien en el campo de la Arqueología Urbana son muchos los esfuerzos que se hacen en este sentido, como se ha encargado de señalar últimamente el propio Brogiolo (2007: 27-28). Con todo, estos límites resultaban restrictivos para el análisis que pretendíamos del sistema urbano vitoriano, y por esa razón hemos preferido diseñar un marco más ajustado a nuestras necesidades. Como es evidente, la definición de este elenco de escalas ha comportado un grado de subjetividad nada desdeñable, aunque creemos que se ha tratado de ese tipo de subjetividad que para Carandini es absolutamente pertinente: «Sin probar el drama de la pérdida de objetividad no estaremos nunca seguros de haber utilizado hasta el mínimo indicio como ladrillo para erigir nuestra construcción histórica» (1996: 138).

\subsection{Redes y relaciones estratigráficas}

El concepto de red es fundamental para la comprensión de cualquier sistema. Los primeros en percibir este tipo de esquemas de organización fueron, en los años 20, los ecólogos que estudiaban las redes de alimentación, después el concepto se extendió a otras ciencias (Capra, 1998: 100). Los geógrafos la conciben en tres sentidos: a) como polarización de puntos de atracción y difusión, que es el caso de las redes urbanas; b) como proyección abstracta, que es el caso de los meridianos y paralelos en la cartografía del globo, y; c) como proyección concreta de líneas de relaciones y conexiones, que es el caso de las redes 


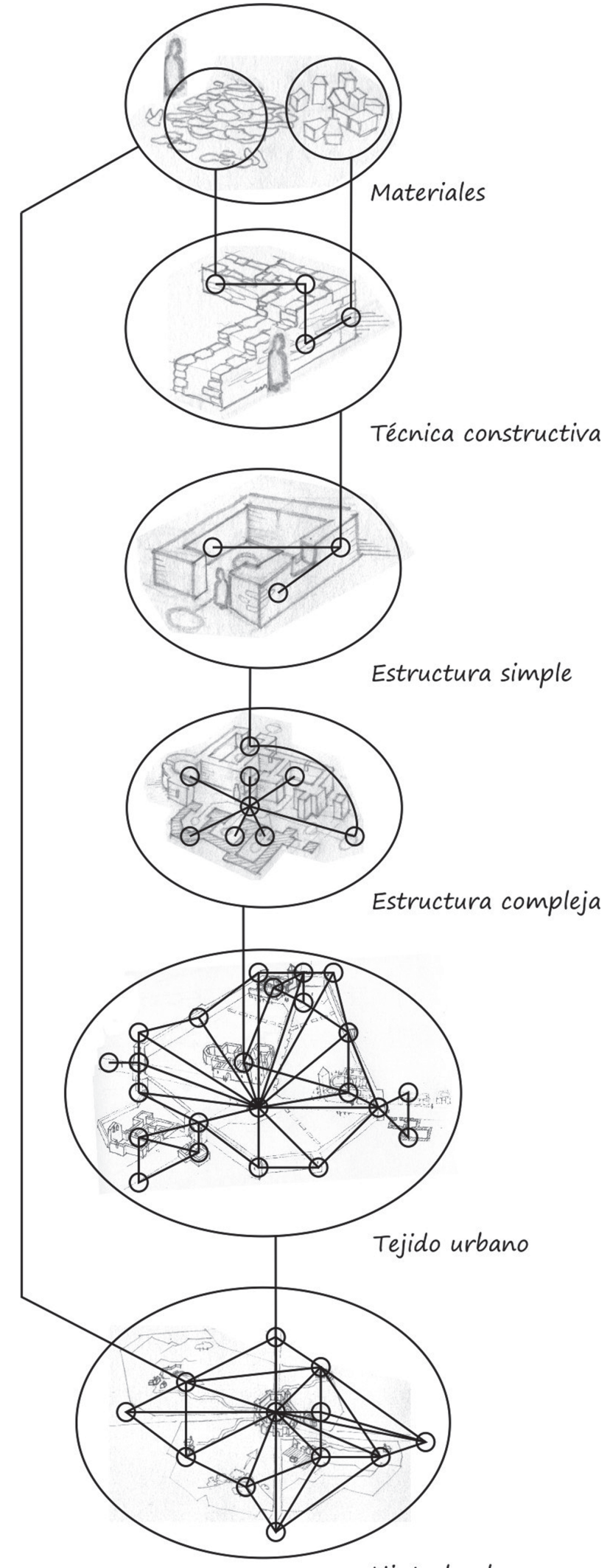

Hinterland

Fig. 10. Patrón reticular. Según M. Santos, el espacio está formado por un conjunto indisoluble de sistemas de objetos y acciones. En esta vista esquemática de nuestro sistema urbano, los círculos representan los objetos, y las líneas, las relaciones/ acciones que los ligan hidrográficas, las redes técnicas territoriales, etc. (Santos, 2000: 222). Por otra parte, ha sido la capacidad de abstracción de los matemáticos la que ha permitido la representación gráfica de estos esquemas de tan difícil comprensión: "las redes o 'grafos' han sido un campo de investigación muy activo entre los matemáticos (...) un grafo es una representación abstracta de un sistema cualquiera, en el que los elementos del sistema o 'nodos' se relacionan entre si mediante conexiones que indican la presencia de una interacción» (Solé, 2009: 32-33).

Prácticamente todo lo que nos rodea responde a algún patrón o esquema de tipo reticular; por supuesto en el mundo biótico («si vemos vida, vemos redes», Capra, 1998: 100 ), por ejemplo, en el modo en que se organizan las neuronas del cerebro, pero también en la configuración de los transportes, en las infraestructuras energéticas, en los sistemas de información o en la interconexión de los mercados. La red es también social, política, técnica, religiosa, si bien debemos insistir - a despecho de la materialidad con que se impone a nuestros sentidos-que la red es, en realidad sobre todo, una abstracción, una herramienta de comprensión (Santos, 2000: 222).

El esquema reticular también subyace en la organización y estructura del entramado urbano de Vitoria-Gasteiz (Fig. 10). De hecho, si se revisa lo apenas comentado en el epígrafe 4.3., creemos que se percibirá con claridad el hecho de que los distintos niveles de profundización propuestos podrían expresarse de forma sintética simplemente aludiendo a la red de objetos que interaccionan en cada una de las escalas; las remesas de distintos tipos de piedra (a), los muros que se diferencian según el modo en que se compone aquellos materiales pétreos (b), las habitaciones que se articulan mediante la erección de esos muros (c), los edificios que se conforman a partir del encadenamiento de habitaciones (d), el coágulo de edificios que da lugar a la ciudad (e), o la constelación de poblaciones que forman el hinterland vitoriano (f).

La división en escalas que hemos propuesto puede resultar, a primera vista, contradictoria con respecto a nuestro discurso (puesto que al diseccionar la globalidad se destruye el sistema como tal), pero no proponemos las distintas escalas como cajones estancos, rellenos de colecciones de objetos aislados, sino como método de clasificación útil para ordenar de forma más fácilmente comprensible los nodos de esa compleja retícula que es todo sistema urbano. A partir de esa visualización en distintas escalas nos resultará más sencillo hacer inteligibles las relaciones, o dicho de otro modo, podremos cartografiarlas de un modo comprensible. 
En esta línea, nos pareció un buen punto de partida el planteamiento del geógrafo M. Santos, para quien el espacio está formado por un conjunto indisoluble («solidario y también contradictorio») de sistemas de objetos y sistemas de acciones, por supuesto, no considerados aisladamente, sino como el contexto único en que se realiza la historia. Según Santos, los sistemas de objetos y sistemas de acciones interactúan; por un lado, los sistemas de objetos condicionan la forma en que se dan las acciones y, por otro lado, el sistema de acciones lleva a la creación de objetos nuevos o se realiza sobre objetos preexistentes; «así, el espacio encuentra su dinámica y se transforma» (2000: 54-55). Siguiendo este planteamiento, el sistema de objetos de nuestro trabajo sería toda esa colección de elementos, componentes de la urbe antes aludidos (y clasificados en sus distintas escalas), mientras que el sistema de acciones sería más bien el sistema de relaciones que debería regir la convivencia entre los objetos; porque en definitiva, las acciones las producen los objetos y ellos son también los que reciben los efectos.

En abstracto, el esquema gráfico que se derivaba de esta concepción era necesariamente reticular (los objetos serían los nodos donde confluirían las líneas que represen$\tan$ acciones/relaciones), lo cual de forma espontánea nos recordó a un tipo de esquema en red con el que estábamos bastante familiarizados; el del diagrama estratigráfico. Un tipo de diagrama que responde por completo a los parámetros de representación grafica de las 'redes' o 'grafos' en tanto que se trata una representación abstracta: «una representación global de la estratigrafía no puede ser topográfica, es decir, realista, sino solo estratigráfica, es decir, reducida a la única dimensión del tiempo relativo, lo que comporta el paso del verismo al simbolismo" (Carandini, 1996: 79).

Reflexionando sobre representaciones gráficas abstractas, no pudimos sino reafirmarnos en la convicción de que la «argamasa» de nuestro edificio teórico estaba precisamente en las relaciones estratigráficas, y que, de hecho, era el enfoque estratigráfico el mejor anclaje de nuestro trabajo a los presupuestos sistémicos (recordemos, "para el pensador sistémico las relaciones son prioritarias", Capra, 1998: 57). Las relaciones estratigráficas funcionan en todas las escalas propuestas — no sólo en las más asiduamente tratadas por la arqueología de campo (las estructuras simples y complejas de nuestra nomenclatura)—, conectando objetos no sólo dentro de cada uno de ellas, sino también entre escalas distintas. Constituyen además la plasmación física de las acciones —antrópicas o naturales- de erosión, transporte y deposición; más adelante volveremos sobre esta cuestión fundamental.

\subsection{Patrón y estructura}

H. Lefebvre, concebía el urbanismo de la ciudad como la forma pura «el punto de encuentro, el lugar de una congregación, la 'simultaneidad'. Esta forma no tiene ningún contenido especifico, sin embargo todo se acomoda y vive en ella. Es una abstracción, pero contrariamente a una entidad metafisica, es una abstracción concreta, ligada a la práctica» (1972: 125). En el enunciado de Lefebvre — sólo aparentemente confuso- subyacen dos niveles de comprensión que si bien no pueden existir por separado, requieren una mínima disección que permita el análisis; hablamos de diferenciar lo abstracto de lo concreto en la forma urbana.

A decir de los especialistas, la perspectiva sistémica es esencialmente un enfoque de patrones, patrones reticulares como los que acabamos de tratar en el epígrafe precedente. No obstante, con ser fundamental, la comprensión del $p a-$ trón no resulta suficiente si no va acompañada de la descripción de la estructura del sistema. Es importante diferenciar ambos conceptos; así, por patrón de organización del sistema entendemos la configuración de las relaciones entre sus componentes, la red antes aludida, que determina las características esenciales del sistema (Figs. 11 y 12). Por estructura del sistema entendemos sin embargo la corporeización física de su patrón de organización. Mientras que la descripción del patrón de organización implica una cartografía abstracta de relaciones, la descripción de la estructura implica el relato concreto de las características formales de sus componentes físicos ${ }^{26}$ (Capra, 1998: 172).

A lo largo de nuestras investigaciones sobre el entramado urbano de Vitoria nos hemos esforzado en hacer justicia a los dos niveles de comprensión, si bien es verdad que la descripción de la estructura, del cuerpo físico de la ciudad (tal como lo perciben nuestros sentidos) y de los elementos que la componen, ha recibido nuestra mayor atención.

No obstante, en no pocas ocasiones también hemos recurrido a la esquematización, con el fin de buscar los

\footnotetext{
${ }^{26}$ Capra propone el siguiente ejemplo práctico: «Para ilustrar la diferencia entre patrón y estructura, tomemos un sistema no vivo bien conocido: una bicicleta. Para que algo pueda ser llamado una bicicleta, deberá existir un número de relaciones funcionales entre sus componentes conocidos como cuadro, pedales, manillar, ruedas, cadena, ruedas dentadas, etc. La configuración completa de estas relaciones funcionales constituye el patrón de organización de la bicicleta. La estructura de la bicicleta es la manifestación fisica de su patrón de organización en términos de componentes de formas especificas, hechos materiales especificos. El mismo patrón 'bicicleta' puede manifestarse a través de muchas estructuras distintas. El manillar tendrá distinta forma para una bicicleta de paseo, otra de carreras y una de montaña; el cuadro podrá ser pesado y sólido o ligero y delicado, los neumáticos podrán ser estrechos o anchos, tubulares o macizos. Todas estas combinaciones y muchas otras serán reconocidas como diferentes manifestaciones fisicas del mismo patrón de relaciones que define a una bicicleta» (1998: 173).
} 


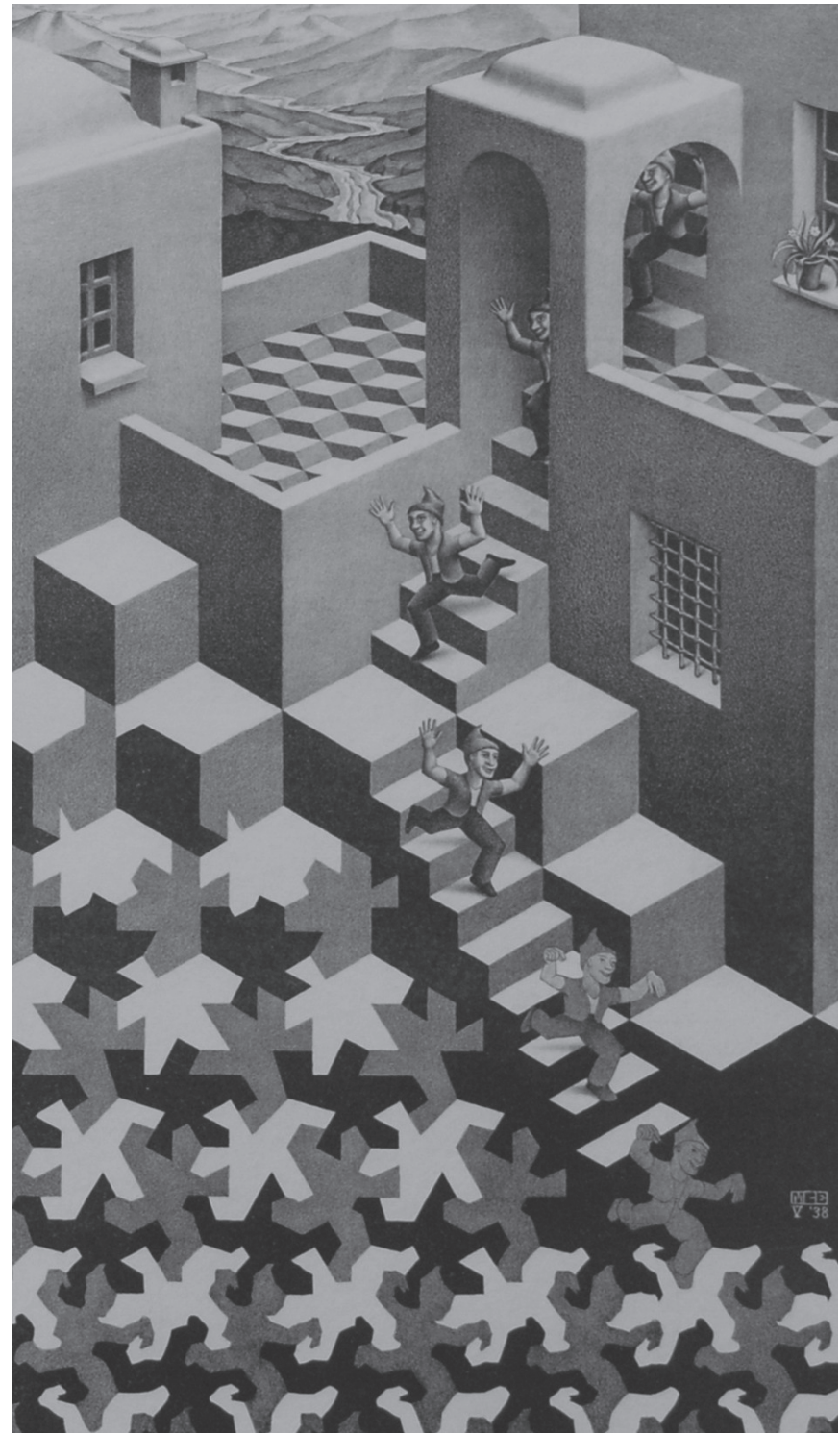

Fig. 11. Siempre hay un patrón de organización que subyace en la forma de cualquier estructura. M. C. Escher, Ciclo

patrones de organización que están detrás de la estructura evidente. El diagrama estratigráfico, también conocido como matrix Harris es un ejemplo de esto último, pero también hemos acudido a formulaciones sencillas de los llamados ' 'y-maps', 'interface maps' o 'decomposition maps' de Hillier y Hanson (2001: 97-122).

\subsection{Estructuras disipativas ${ }^{27}$ y proceso}

El edificio o la ciudad tienen en común con el organismo vivo la necesidad de degradar continuamente energía

${ }^{27}$ Puede decirse que estructura disipativa es el término prácticamente sinónimo que emplea F. Capra para referirse a los sistemas termodinámicos abiertos. Éste a su vez toma el término del químico y físico de origen ruso I. Prigogine (1998: 103).
Patrón

Estructura

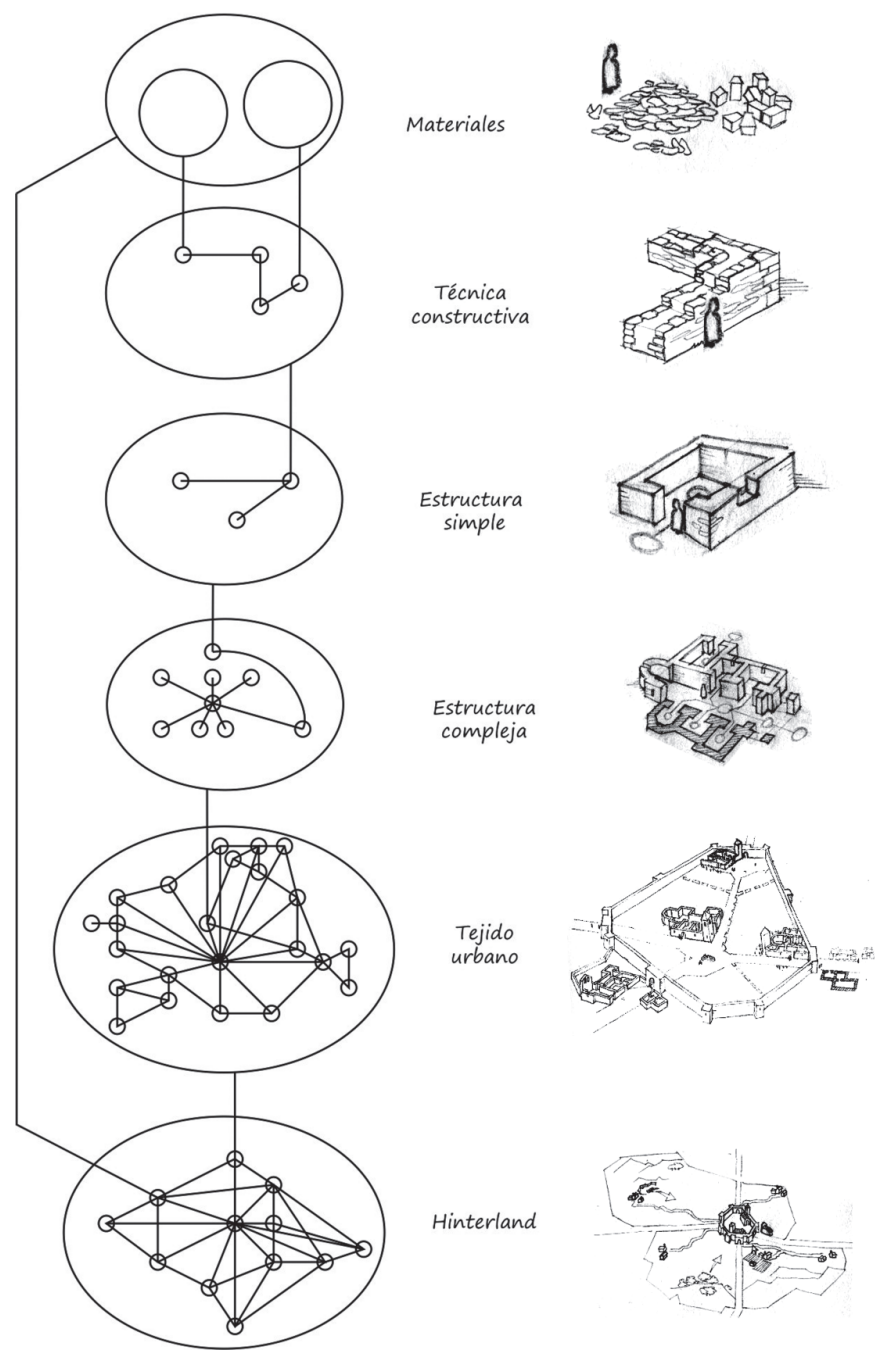

Fig. 12. Por patrón de organización del sistema entendemos la configuración de las relaciones entre sus componentes que determina las características esenciales del sistema. Por estructura del sistema entendemos sin embargo la corporeización física del patrón de organización

para mantener la organización morfológica que se halla en la base de su existencia. Si observamos una ciudad, una población cualquiera, entendemos que se les considere sistemas termodinámicos abiertos, en tanto que percibimos como algo evidente que viven de su apertura, es decir, que subsisten gracias a los flujos de materia y energía que intercambian con del mundo exterior. Cualquier ciudad, separada de su medio, se desintegraría rápidamente. Por decirlo de otro modo, la ciudad es la encarnación, local y singular, de los flujos que no dejan de transformarla (Fernández-Galiano, 1991: 90).

Señalaba I. Prigogine que la ciudad existe sólo en situación de no-equilibrio: «La ciudad vive gracias a que intercambia materias primas o energía con el campo que la 
Fig. 13. La ciudad como permanente proceso de construcción. Preocupado por hacer creíble el discurso de su cuadro, Brueghel entendió que el proceso de construcción de un edificio de las características de la torre de Babel no podía haber tenido lugar sino en el contexto de un abigarrado sistema urbano. En la imagen, la ciudad aparece bien diferenciada de su hinterland por medio de las murallas, pero estas murallas transpiran; a través del puerto y los accesos al recinto mural que vemos a la derecha, al pie de la torre, la ciudad y el edificio reciben las materias primas que le son imprescindibles para subsistir

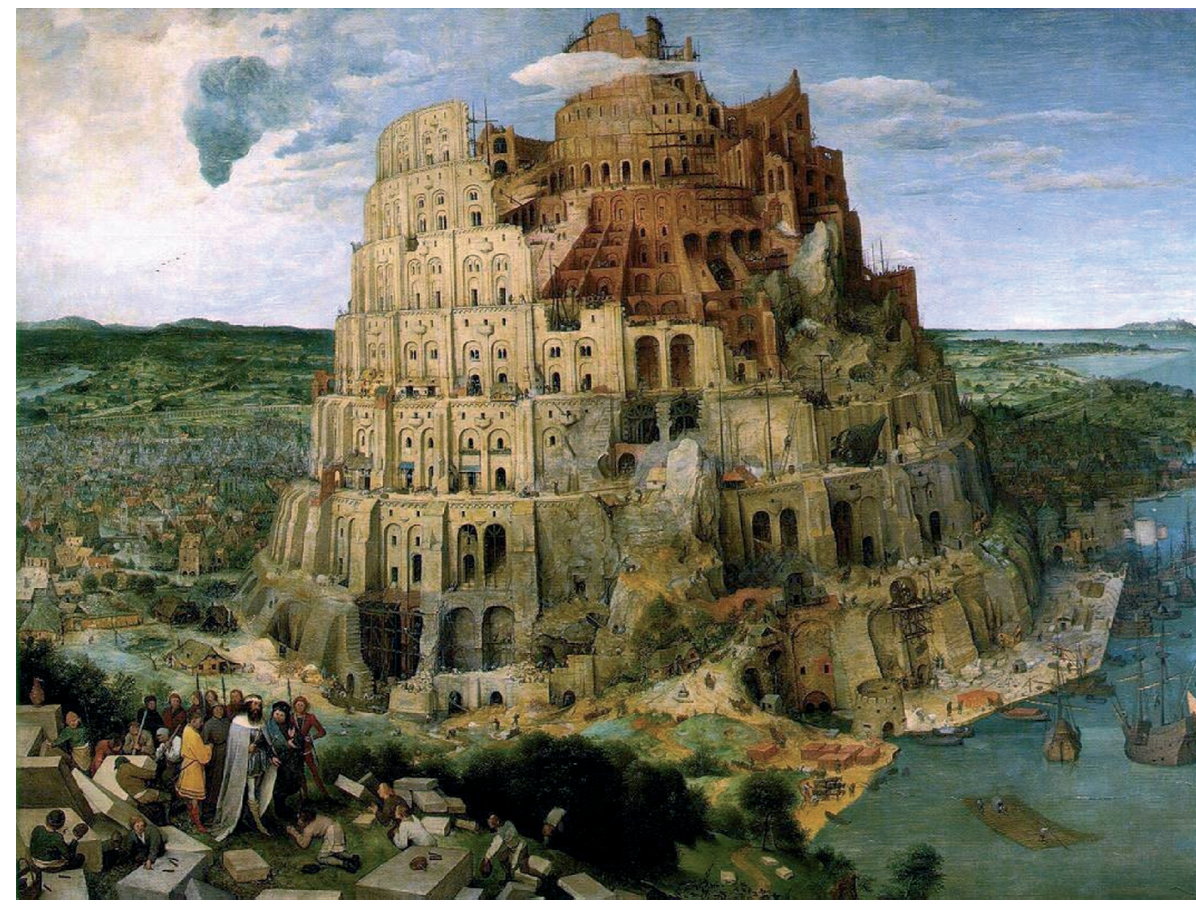

circunda. Es la función la que crea la estructura. Pero la función, el flujo de materia y de energía, es evidentemente una situación de no-equilibrio» (2005: 34). Efectivamente, mientras que en un sistema sencillo, como por ejemplo una bicicleta o un molino, las partes han sido diseñadas, fabricadas y ensambladas para formar una estructura de componentes fijos, en un sistema complejo como la ciudad, los componentes mutan continuamente, se sintetizan y asumen nuevas estructuras, o se eliminan las sustancias sobrantes. En definitiva, la ciudad dispone de su propio metabolismo ${ }^{28}$. En la ciudad, los nuevos trazados urbanísticos se agregan, se superponen o directamente sustituyen a los antiguos; generación tras generación, los distintos contingentes humanos se suceden; hay crecimiento, desarrollo y evolución. No obstante, el metabolismo de la ciudad no debe medirse sólo en la dimensión material; la ciudad también asume ideas, adopta -y adapta- formas de organización o estructuras sociales que después comparte con el resto de poblaciones de su entorno. En este sentido, algunos investigadores no dudan

${ }^{28}$ Como señalara Wolman: "Las exigencias metabólicas de la ciudad suelen ser definidas como la suma de todas las materias y productos que aquella necesita para el sostén de sus moradores, tanto en sus hogares como en sus trabajos y en sus esparcimientos. Entre esas exigencias hay que incluir también — para un determinado periodo de tiempo - los materiales destinados a la construcción -o a la reconstrucción - de la propia ciudad. El ciclo metabólico no se considera cerrado hasta que los desechos y detritus que la vida cotidianamente va acumulando han sido recogidos y eliminados con un minimun de molestia y riesgo" (1982: 199). en afirmar que, desde un cierto punto de vista, la ciudad aprende ${ }^{29}$.

Esta sorprendente propiedad de algunos sistemas, sugiere el proceso como tercer criterio para una completa descripción de la naturaleza de una ciudad. En tanto que el proceso es la actividad que se ocupa de la continua corporeización del patrón de organización del sistema, el criterio de proceso constituye el vínculo entre patrón y estructura. No obstante, resulta imposible abordar ni siquiera en el marco de las investigaciones más ambiciosas todos los procesos que confluyen en el metabolismo de una ciudad, ni siquiera ciñéndonos a un estadio evolutivo primario de la urbe, como podría ser el caso de la Gasteiz medieval. Por ello, en nuestras investigaciones hemos dejado a un lado la mayoría de las formas de absorción metabólica (como alimento, vestuario, bienes durables, o materiales combustibles, etc.), para concentrarnos, por un lado, en el meta-

\footnotetext{
29 S. Johnson se cuestiona: "iAprenden las ciudades, no los individuos que las pueblan, no las instituciones que las apadrinan, sino las ciudades mismas? Pienso que la respuesta es que sí (...) El aprendizaje es una de las actividades que habitualmente asociamos al conocimiento consciente, como enamorarse o llorar la pérdida de un familiar. (...) Pero el aprendizaje no depende de la consciencia. (...) Por ejemplo, nosotros no venimos a este mundo predispuestos a combatir el virus de la varicela; sin embargo nuestros cuerpos aprenden a hacerlo sobre la marcha, sin consciencia, sin ningún entrenamiento especifico (...) El cuerpo aprende de forma inconsciente, y lo mismo ocurre con las ciudades, porque el aprendizaje no consiste únicamente en ser conscientes de la información; es también una cuestión de almacenar información y saber dónde encontrarla. (...) El sistema no necesita ser consciente de que es capaz de ese tipo de aprendizaje, al igual que nuestro sistema inmunológico no necesita ser consciente de que aprende a protegernos de la varicela» (2003: 92-93).
} 
bolismo relacionado con los materiales de construcción — sustancia esencial del tejido urbano- y, por otro, en lo referente a la asimilación y desarrollo las formas de edificar, y a los modos de articular socialmente el espacio (Fig. 13).

\subsection{Retroalimentación (feedback) y recursividad}

Originalmente, en matemáticas, un bucle de retroalimentación corresponde a una determinada clase de proceso nolineal conocido como iteración, en el que una función opera reiteradamente sobre sí misma, o dicho de otro modo: "un bucle de retroalimentación es una disposición circular de elementos conectados causalmente, en la que una causa inicial se propaga alrededor de los eslabones sucesivos del bucle, de forma que cada elemento tiene un efecto sobre el siguiente, hasta que el último 'retroalimenta' el efecto sobre el primer eslabón en que se inició el proceso. (Capra, 1998: 75 y 140).

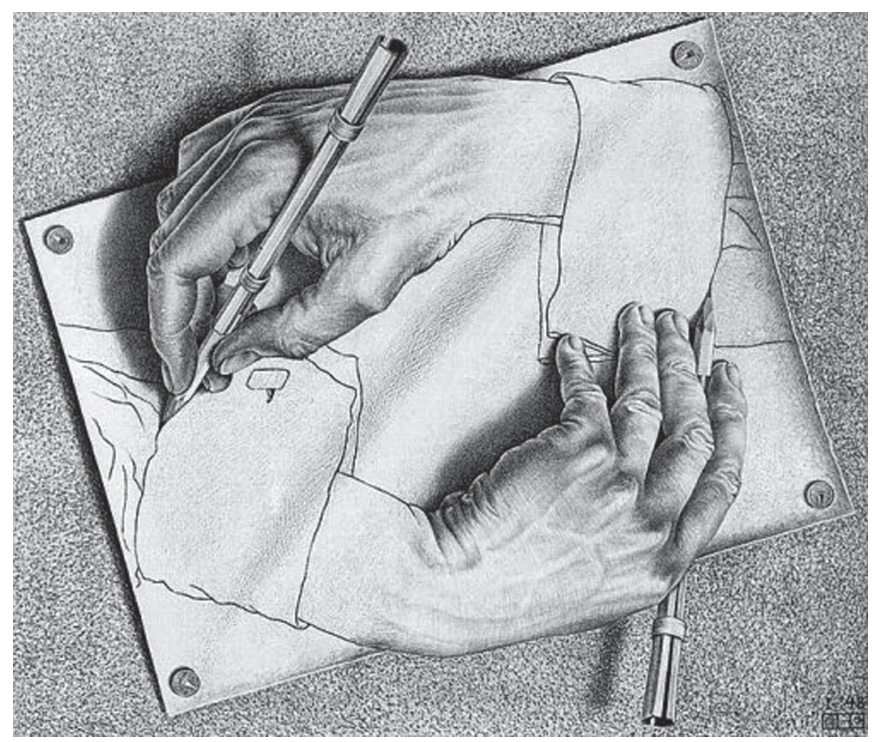

Fig. 14. Retroalimentación. "Según es generalmente sabido, el modelo básico es un proceso circular en el cual parte de la salida es remitida de nuevo, como información sobre el resultado preliminar de la respuesta, a la entrada, haciendo así que el sistema se autorregule, sea en el sentido de mantener determinadas variables o de dirigirse a una meta deseada» (Bertalanffy, 1976: 167). M. C. Escher, Manos dibujando

En la práctica, todos los sistemas complejos que nos rodean (desde nuestro sistema neuronal a los circuitos integrados de un ordenador, desde la colonia de hormigas hasta la sociedad de la que participamos) funcionan en base a la retroalimentación (Figs. 14 y 15). Reflexionemos concretamente sobre la urbe. Arquitectura y urbanismo se basan en el reforzamiento de los hábitos básicos que requieren el individuo y la sociedad para su existencia, hábitos que en sí mismos son ciclos retroalimentados cuya pretensión es el sostenimiento de esos otros sistemas que son el cuerpo humano y la sociedad; nos referimos entre otros a circular, dormir, comer, beber o deponer, pero también orar, dialogar, intercambiar, etc. Según esta lógica del bucle, en principio, cuanto más frecuente sea el uso de una vía de comunicación, más posibilidades habrá de que la comunidad se preocupe por mejorar el camino, y cuanto mejor sea el camino más tráfico atraerá y más se erosionará, de modo que dicha comunidad deberá invertir más en el mantenimiento, y así sucesivamente. En un sistema complejo como la ciudad los pequeños cambios pueden tener efectos espectaculares, ya que pueden ser repetidamente amplificados por la retroalimentación reforzadora, esto se debe a que los ciclos retroalimentados están siempre enlazados unos a otros.

Los ciclos pueden estar interconectados — por así decir, de igual a igual- dentro de una misma escala ${ }^{30}$, pero también pueden encadenarse interescalarmente, de modo que el mínimo cambio en los ciclos de los niveles inferiores puede desencadenar un efecto en cadena con gran repercusión en los ciclos de mayor escala ${ }^{31}$; es la consecuencia de lo que Hofstadter denomina específicamente recursividad ${ }^{32}$.

Retroalimentación y recursividad han estado siempre en la base de la interpretación de los procesos históricos. Pensemos por ejemplo, en el caso de un conocido ciclo retroalimentado, tratado con frecuencia por la historia económica medieval; la rotación de cultivos. Este ciclo (introducido a fines del siglo VIII), al mejorar la productividad del suelo, favoreció en principio la obtención de nutrientes y el crecimiento demográfico (White, 1973: 8593). Una de sus consecuencias probables: el crecimiento de los núcleos de población. Con su mayor tamaño poblacional, las aglomeraciones fueron capaces de generar mayor cantidad de residuos, que en gran parte pudieron ser reutilizados como fertilizante en el campo, lo que aumentaría la productividad del suelo (Johnson, 2003: 100). En este ejemplo, apreciamos retroalimentación (puesto que advertimos como el primer eslabón se ve afectado por el

\footnotetext{
${ }^{30}$ Por ejemplo, las mejoras en el aprovechamiento de la fuerza del agua corriente de los ríos afectarán tanto a la molienda, como a la elaboración del hierro en las ferrerías, es decir, tanto al ciclo productivo cerealícola como al ciclo productivo del hierro.

${ }^{31}$ Siguiendo la concepción sistémica de que un ciclo percibido a cierta escala está compuesto a su vez de ciclos que sólo se perciben en una escala inferior, y de que éstos a su vez están conformados por otros ciclos que funcionan a una escala aún menor, etc.

32 "QQué es la recursividad? Incrustaciones y variaciones de incrustaciones. El concepto es muy amplio (relatos dentro de relatos, películas dentro de películas, muñecas rusas dentro de muñecas rusas (o comentario entre paréntesis dentro de comentarios entre paréntesis), son solamente algunos de los encantos de la recursividad)" (Hofstadter, 2005: 141).
} 

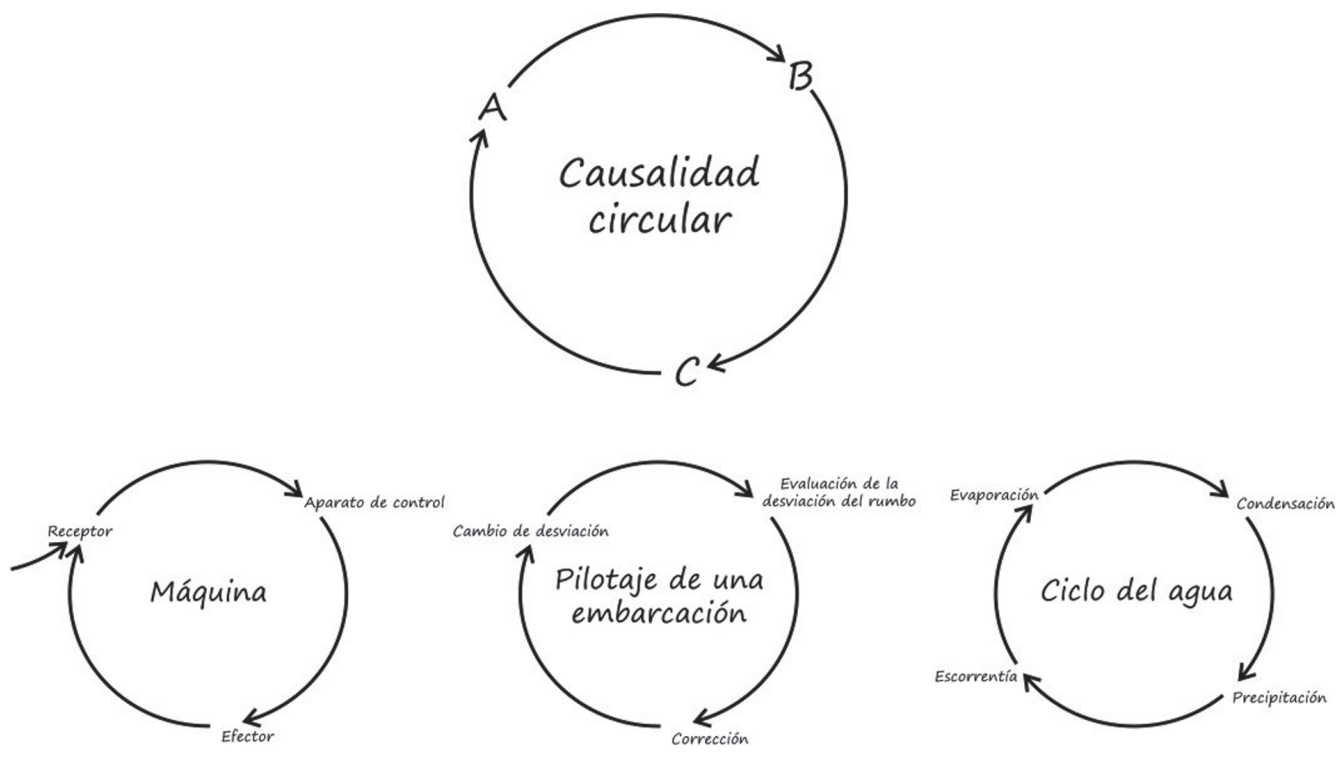

Fig. 15. Ejemplos de causalidad circular

último) $^{33}$, pero también apreciamos la recursividad, porque lo que en origen sólo era de un avance tecnológico puntual que pretendería aumentar la productividad de una explotación -y mejorar las condiciones de vida de sus beneficiarios directos-, debido al éxito y difusión de la fórmula, pudo acabar transformando a escala continental el régimen demográfico de la población europea (debemos señalar no obstante, que por supuesto, fenómenos a gran escala, como el del crecimiento demográfico entre los siglos VIII y XI, nunca responden a un único factor detonante sino que son el resultado de la confluencia de un conjunto de ellos) ${ }^{34}$.

Por supuesto, mecánicas de este tipo subyacen tanto en los períodos de crecimiento como en sus contrarios. ¿Qué decir de las pandemias y los mecanismos utilizados por los virus para su contagio?, la retroalimentación

${ }^{33}$ Lo cual se traduce en la autorregulación de todo el sistema, al verse modificado el estímulo inicial a lo largo de cada recorrido por el circuito.

${ }^{34}$ En este caso, más allá de la rotación de cultivos habría que hablar también de otros aspectos tecnológicos y no tecnológicos: "Ya no es aceptable la hipótesis de una 'revolución', considerada como un 'cambio brusco' o un 'salto adelante' claramente delimitado en el tiempo. En cambio, parece poco dudoso que la sociedad medieval hubiese sido la matriz de un conjunto coherente de progresos en el utillaje y las técnicas. Hablemos de 'sistema técnico' para denominar a este conjunto. Sus elementos se organizaron progresivamente desde la alta Edad Media y quedó configurado, como muy tarde, en el siglo XII. El sistema comprende a la vez el dominio de energía, el utillaje y las formas de cultivo" (Bois, 2001: 22). Bois habla además de otros factores; de la difusión del molino de agua, del molino de viento, de la 'democratización' del hierro y la mejora de los instrumentos aratorios, también de la mejora en el utillaje de labor y de tiro entre otros, llamando la atención sobre otras variables no estrictamente tecnológicas; la propia expansión de los burgos como 'revolución ignorada', la monetarización de la sociedad, la promoción del trabajo, el desarrollo del mercado, etc. (Ibidem 20-62). también estuvo presente en fenómenos como el de la Peste del XIV. Ahondando en esta idea, G. Bois señala por ejemplo la deflación como clave central de la crisis bajomedieval, optando para su descripción por un sinónimo de retroalimentación, a saber, autoalimentación: «Si la evocación de la palabra produce escalofrios, es por el efecto destructor que todos coinciden en reconocer a la 'deflación'. El movimiento se 'autoalimenta'; descenso de los precios y de la producción se refuerzan mutuamente en un deslizamiento que puede volverse dramático. (...) El problema consiste en comprender los principales mecanismos de la espiral” (2001: 104). Según Bois, el deshinchamiento de la burbuja especulativa, la contracción de oferta y de la demanda son los factores detrás de la crisis bajomevieval. Se trata de los ciclos que - hacia arriba - desencadenan el gran bucle de la crisis, los mismos que - hacia abajo- se pueden subdividir en nuevos ciclos hasta alcanzar el caso puntual, el comportamiento individual: «Aqui tocamos la parte sumergida del iceberg económico. Cada burgués, cada notable, estaba al frente de un patrimonio inmueble de un valor respetable. (...) Ahora bien, el valor mercantil de estos bienes no habia cesado de ascender beneficiándose del crecimiento urbano (...) entre el coste del inmueble urbano y los ingresos salariales se habia abierto una distancia considerable (...) Dicho de otra manera, el sector inmobiliario, que representaba una gran proporción de los activos de los ricos, se habia beneficiado de lo que hoy llamariamos una 'burbuja especulativa'» (Ibidem: 106). Obsérvese por tanto cómo la crisis bajomedieval hunde una parte importante de sus raíces en las dinámicas del sistema urbano y cómo, por otro lado, es 


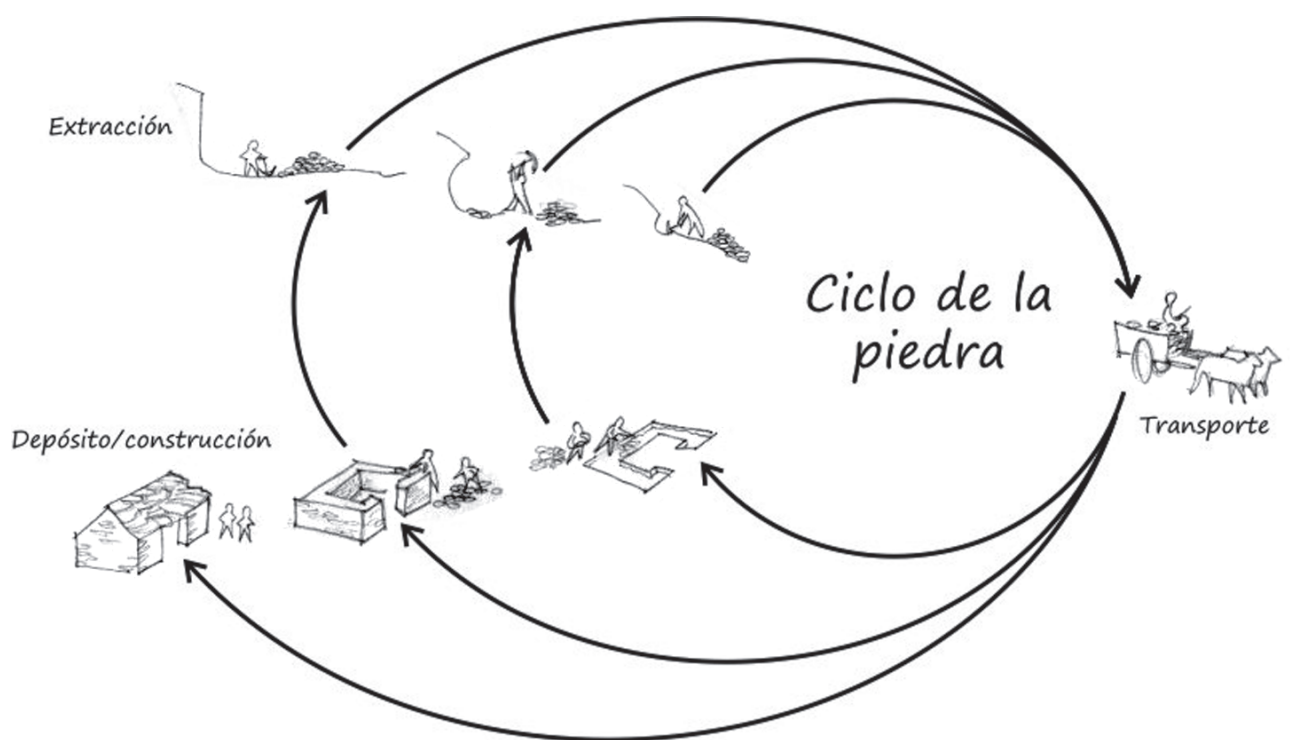

Fig. 16. Los ciclos retroalimentados están muy presentes en Arqueología. En la imagen, una visión sintética de la parte del ciclo de la piedra que respecta a la construcción de un edificio

la retroalimentación la que hace que una multiplicidad de actos individuales puedan convertirse en fenómenos imprevisibles a gran escala. Se trata según P. Krugman, de una suerte de organización espontánea de la economia ${ }^{35}$.

El propio Krugman nos revela que los procesos de retroalimentación afectan no sólo a las transacciones económicas sino también a la organización del espacio urbano. Sus investigaciones se refieren a las grandes metrópolis modernas, o mejor, a las edge cities, pero al leer sus conclusiones resulta difícil sustraerse a la sospecha de que quizá la distribución espacial de las distintas actividades en la ciudad medieval no se rigiera por pautas de segregación muy diferentes a las de las empresas actuales (modelo de segregación de Schelling, 1997: 24-32).

En cualquier caso, la retroalimentación también ocupa un espacio importante en el campo de la Arqueología. La percibimos por su puesto en la génesis de la estratificación (el ciclo de erosión/destrucción, movimiento/transporte y depósito/acumulación, Carandini, 1996: 25) pero también la encontramos presente en los procesos de generación de la cultura material, los ciclos productivos de Mannoni y Giannichedda (2004). Según estos autores, los ciclos productivos preindustriales pueden ser descritos como secuencias de operaciones que permiten transformar un material en un producto con características diversas: «en teoría, cada una de estas actividades se podría subdividir posteriormente,

\footnotetext{
35 "Consideramos que hemos logrado arrojar luz sobre un fenómeno cuando conseguimos demostrar cómo ese fenómeno - el 'macrocomportamiento'- emerge de la interacción de decisiones de familias o empresas aisladas. Los modelos más satisfactorios serian aquellos en los que el comportamiento resultante es más sorprendente si lo comparamos con los 'micromotivos' de los participantes» (Krugman, 1997: 23).
}

iniciando con ello un proceso que sólo tendría su fin cuando se aislase cada gesto técnico precedente o sucesivo. De esta forma, para cada uno de estos gestos se deberían separar también los caracteres específicos de cada persona, entre ellos la anatomía, la psicomotricidad, la voluntad y la atención.» (2004: 77). Como vemos, en los ciclos productivos también hay sitio para la recursividad.

En nuestra investigación hemos prestado una especial atención al ciclo productivo de la piedra ${ }^{36}$ en tanto que es la materia fundamental a partir de la cual se ha estructurado la mayor parte del patrimonio construido que ha llegado a nosotros (Fig. 16). Por supuesto, existen otros ciclos igualmente importantes en la generación de la estructura urbana que merecerían un tratamiento específico; el ciclo productivo de la madera por ejemplo, imprescindible en la arquitectura preindustrial (pensemos en las cabañas de la Gasteiz del siglo VIII, y aún en la estructura interna de cualquier inmueble vitoriano hasta mediado el siglo XX), o el ciclo de la cerámica para el conocimiento de la conversión de arcillas en adobes o ladrillos. No obstante, hemos tenido que optar por uno sólo de estos ciclos con vistas a no exceder nuestras posibilidades.

\subsection{Sociología del error y marco cronológico de nuestros trabajos}

Tradicionalmente, la historia del conocimiento se centra en los exitosos pasos hacia adelante, en las ideas vanguardistas y en los saltos conceptuales; nula o escasa atención

${ }^{36}$ Sin olvidar uno de los procesos que dentro de éste y los demás ciclos se puede calificar como más genuinamente 'retroalimentado', el reciclaje de materiales. 
Fig. 17. La evolución puede entenderse como una gestión sistemática del error. La Pirámide Romboidal es probablemente el

eslabón más expresivo de la evolución arquitectónica de las pirámides; un error de cálculo obligó a corregir la inclinación de sus caras sobre la marcha. Esta experiencia sirvió para los siguientes prototipos. A otro nivel, en San Pedro de Vitoria, vemos como los contratiempos se acaban gestionando con éxito; la idea original (A) era construir un templo completamente nuevo (morado) desechando el primitivo (naranja), pero la nueva obra no avanzó lo deseado debido a la falta de recursos (B), los artífices optaron

por una solución más económica, unir mediante un cuerpo de fábrica imprevisto en los plantes originales (rosa), lo viejo, con

lo poco que se había logrado hacer de lo nuevo. De ahí las anomalías que presenta la planta del edificio actual
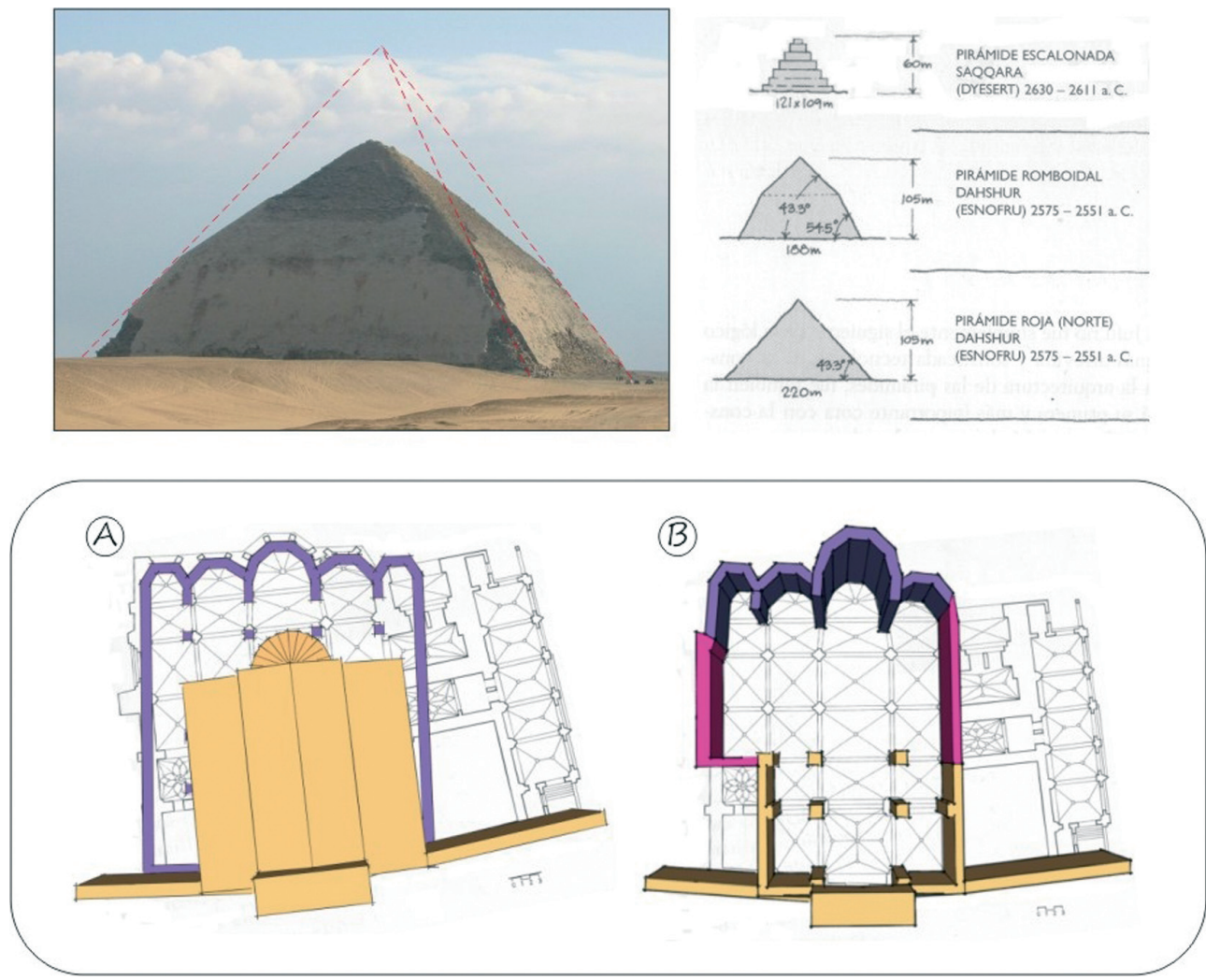

reciben sin embargo las ideas o proyectos fallidos, aquellos oscuros continentes del error y del perjuicio. Revelándose ante lo que juzga una carencia en la historia del conocimiento, S. Johnson defiende precisamente la sociología del error $^{37}$ como una de las mejores vías para alcanzar una comprensión integral del hecho de la evolución humana (2008: 17). En la misma línea, K. Kelly llega incluso a interpelarnos: «honrad vuestros errores» (2002: 140).

Según estos autores, para avanzar más allá de lo ordinario se requieren siempre nuevos espacios de trabajo, lo que implica en cierta medida el abandono de los métodos o territorios convencionales; una aventura que tiene sus peligros, y cuyas consecuencias son a menudo indiscernibles de lo que llamamos error. Incluso el acto más brillante de la mente humana es un acto de ensayo y error. Kelly afirma que el Error, aleatorio o deliberado, debería convertirse en una parte integral de cualquier proceso de creación: "La evolución se puede entender como la administración sistemática del error» (Ibidem: 141). No se trata de una afirmación novedosa, ya a mediados del siglo XX, T. S. Kuhn apuntaba que la percepción de la

${ }^{37}$ S. Johnson añade: "El río del progreso intelectual no sólo está definido por el flujo constante de buenas ideas que engendran ideas mejores, sino también en la topografia que le han diseñado factores externos. A veces esa topografia levanta tantos diques que el río retrocede durante un tiempo" (2008: 128). anomalía constituye un componente básico de los descubrimientos científicos (2001: 93). Anomalía no es exactamente lo mismo que error pero ambos términos comparten un mismo esquema conceptual; es lo inesperado frente a lo esperado, el ideal frente a la realidad práctica ${ }^{38}$.

La sociología del error en nuestro trabajo se puede entender a varios niveles. En primer lugar, al nivel de la investigación misma (o incluso al nivel del texto que ahora presentamos). Este artículo es una selección de las reflexiones que han primado en nuestro trabajo, concretamente aquéllas que hemos considerado que nos han permitido alcanzar con cierto éxito los objetivos que nos planteábamos, pero, por su puesto, ha habido otras muchas reflexiones que nos han conducido a dolorosos callejones sin salida, y, cómo no, han quedando fuera de esta presentación. Aún y todo, todas aquellas «erradas» líneas de investigación nos han ayudado a fijar la deriva de nuestro enfoque metodoló-

\footnotetext{
38 "El descubrimiento comienza con la percepción de la anomalía; o sea, con el reconocimiento de que en cierto modo la naturaleza ha violado las expectativas, inducidas por el paradigma que rige la ciencia normal. A continuación se produce una exploración más o menos prolongada de la zona de la anomalía. Y sólo concluye cuando la teoría del paradigma ha sido ajustada de tal modo que lo anormal se haya convertido en lo esperado (...) La percepción de la anomalía -o sea de un fenómeno que el investigador no está preparado por su paradigma- desempeña un papel esencial en la preparación del camino para la percepción de la novedad» (Kuhn, 2001: 93 y $100)$.
} 
gico, logrando dar — creemos — un sentido más profundo y genuino a esas líneas de trabajo «correctas».

En segundo lugar, al nivel de los datos. Investigar en busca de un objetivo u objetivos, errar al trazar la línea para alcanzarlos, en fin, remar durante un tiempo en la dirección equivocada, implica a menudo generar una gran cantidad de datos -en este caso, para el conocimiento de la historia de Vitoria-Gasteiz-, que aun siendo interesantes, sin embargo suelen no cuadrar dentro del marco previsto de una investigación dada, puesto que ésta debe caracterizarse por una línea argumental clara, coherente, compacta y cualquier digresión tiende a producir «ruido».

En tercer lugar, al nivel del conocimiento mismo de los procesos constructivos. Así, salvo quizá en el caso las murallas, podemos afirmar que en los trabajos de erección de los templos vitorianos rara fue la ocasión en la que un proyecto se concluyó en el plazo y las formas previstas al inicio de las obras. A menudo se produjeron interrupciones que dejaron huella en los edificios; hasta el punto de que, a veces, da la impresión de que estos están hechos a base de retales de las más variadas formas y estilos arquitectónicos. Esta constatación podría hacernos pensar en un alto grado de imprevisión, amén de continuos errores de cálculo, por parte de constructores y promotores (Fig. 17). Pero si bien algo de esto hay, la realidad parece que fue más bien otra.

Lo habitual es que los artífices fueran conscientes de que los trabajos se prolongarían durante décadas, circunstancia que se limitaban a aceptar con resignación, de modo que cuando los recursos lo permitían se avanzaba todo lo posible, y cuando no había fondos se esperaba pacientemente hasta poder contar con ellos. Evidentemente, lo lógico era que, al retomar los trabajos, la concepción del proyecto original se hubiera transformado por completo, una reformulación que trataría de aprovechar las nuevas posibilidades técnicas y adecuarse a los cambiantes gustos arquitectónicos. Por supuesto, este no es un hecho exclusivo de Vitoria, se trata de un fenómeno endémico en la arquitectura europea de prácticamente todo el período preindustrial. Erlande-Brandenburg observa: «sorprende la aparente indiferencia de los promotores de obra; éstos, dejaban para sus sucesores el cuidado de arreglar los problemas a medida que se presentaran, mientras ellos se contentaban con solucionar los más inmediatos" (1989: 198). Como vemos, anomalía o error, se asumían como una parte constitutiva del proceso constructivo, haciendo buena la afirmación de K. Kelly antes aludida: «la evolución se puede entender como la administración sistemática del error» (2002: 141).
Es un hecho que apreciamos claramente en la arquitectura de los templos vitorianos; si bien al comenzar la construcción de las distintas iglesias existe una idea más o menos determinada del producto que se pretende obtener, las diversas circunstancias que imponen las interrupciones hacen que el resultado final sea imprevisible, diferente sin duda a la idea original (o a la sucesión de ideas originales, porque cada vez que se reemprende el proyecto se reelabora por completo la idea del producto final a obtener). Sólo aquéllos que desde el presente podemos echar la mirada hacia atrás y apreciar ese producto final como tal podemos hacernos una idea completa del edificio, una perspectiva que muchas veces resulta engañosa porque tendemos a creer que aquello que nosotros percibimos como un todo acabado coincide con la idea original de los primeros constructores: "el acontecimiento sólo es identificable cuando es percibido, es decir, cuando se acaba y se completa. Y el acontecimiento sólo se completa cuando se integra en el medio" (Santos, 2000: 80).

El producto final que hoy percibimos es el fruto de la interacción de todas las obras que se han sucedido en los distintos complejos construidos estudiados hasta bien entrado el siglo Xx. Todos ellos son fundamentales para la comprensión del edificio como edificio completo; en lo constructivo, no hay posibilidad de primar un período sobre otro, porque todos han intervenido de igual modo en la generación del efecto inesperado y actual que constituye cada iglesia. También por ello, en nuestros trabajos, el estudio arqueológico de cada edificio ha sido, digamos, integral en lo cronológico (desde las primeras obras en piedra del siglo XI hasta el siglo XX ${ }^{39}$. Ahora bien, la mayor parte de nuestras investigaciones se centran en el análisis del período medieval y moderno, debido a que entendemos que el conocimiento de los efectos socio-económicos de los procesos constructivos requieren entrar en tal grado de detalle que, intentar mantener la exhaustividad hasta el siglo XX habría hecho inviable ninguna aproximación.

Por último, cabe señalar que este «enfoque del error» es susceptible de ser aplicado tanto al edificio como a la

\footnotetext{
${ }^{39} \mathrm{Al}$ respecto de la importancia de la elección de la escala cronológica adecuada para la percepción de ciertos fenómenos nos parecen muy interesantes las reflexiones de Saura i Carulla: "Para comprender cómo cambia un sistema a lo largo de la historia o descubrir la heterogeneidad de su estructura en el espacio se seleccionan respectivamente escalas temporales y espaciales adecuadas. En principio, la escala espacial o temporal escogida es independiente del nivel o niveles jerárquicos del sistema que se pretendan estudiar. La extensión de la escala espacial viene limitada por las propias dimensiones del sistema. Por su lado, la escala temporal tiene sus limites en la persistencia del sistema en el tiempo. Si bien las escalas y los niveles son en principio interdependientes, es cierto que para estudiar la evolución temporal de un determinado nivel será necesario tomar un tiempo de referencia adecuado para que sea observable su evolución" (2003: 28).
} 
Fig. 18. Un ejemplo muy gráfico de 'autonomía de la acción' puede ser el de la investigación en el campo de la energía atómica. En la foto, los investigadores germanos que con más ahínco la promovieron desde

la esfera científica; no sospechaban las terribles consecuencias que tendría el uso político/bélico de sus descubrimientos pocas décadas más tarde

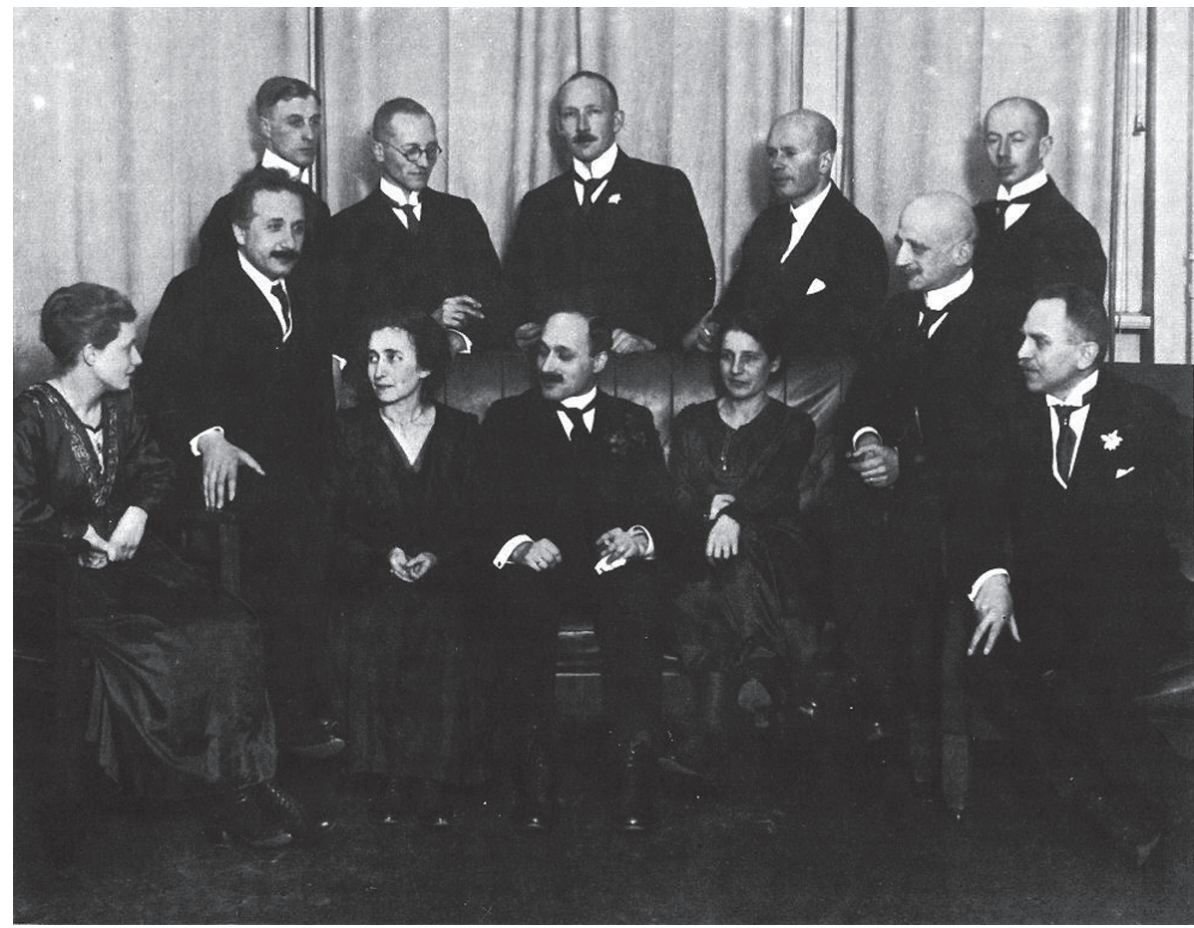

ciudad en su conjunto; como veremos a continuación, la urbe también es un producto heterogéneo, imprevisto, un laboratorio de prueba/error, en fin, el resultado de diseños que se superponen a otros diseños.

\subsection{Autonomía de la acción}

La naturaleza funcional y sociológica del espacio urbano no puede estar preestablecida en un plan, no puede responder mecánicamente a las direccionalidades y los puntos de atracción prefigurados por unos diseñadores, puesto que resulta de un número inmenso e inmensamente variado de movimientos y ocupaciones transitorias, imprevisibles la mayoría, que dan lugar a mapas móviles y sin bordes (Delgado, 2007: 13). En este sentido, M. Santos advierte que la cuota de imponderabilidad de toda acción humana depende de la propia naturaleza humana, pero también del carácter humano del medio, es decir, que al contrario de la producción del conocimiento —imposible de separar del proceso que lo ocasiona-, en el dominio de la acción los resultados están siempre separados de aquel que la produce (Fig. 18) ${ }^{40}$. Esta imprevisibilidad del resultado es conocida como la autonomía de acción (2000: 79-80).

\footnotetext{
${ }^{40}$ Santos es bastante claro en su explicación: «Una razón por la cual no se puede prever completamente el resultado de la acción proviene, exactamente del hecho de que la acción siempre se realiza sobre el medio, combinación compleja y dinámica, que tiene el poder de deformar el impacto de la acción (...) Un acontecimiento es el resultado de un haz de vectores, conducido por un proceso, que lleva una nueva función al medio preexistente» (2000: 79).
}

La construcción de unas murallas con objeto de proteger un asentamiento o para controlar mejor el tráfico local, puede ser un fin conscientemente buscado por el individuo o individuos que deciden promover la creación de una población y su diseño urbano. No obstante, una vez alcanzada la meta principal, no todas las consecuencias que se derivan del proceso puesto en marcha con tal operación entran dentro de los planes previstos por los promotores. La generación de arrabales, el nacimiento de nuevas plazas de mercado inmediatamente por fuera al cinturón mural y otros muchos fenómenos de diversa índole, constituyen una suerte de imponderables, de efectos colaterales o resultados no previstos -quizá incluso no deseados- cuyas consecuencias a menudo sólo pueden ser percibidas en el largo plazo.

El fenómeno urbano de Gasteiz también puede ser interpretado desde la perspectiva de la autonomía de la acción; es decir, como un resultado inesperado, aunque fruto de la interacción de múltiples acciones con resultados esperados. Para Y. Barel por ejemplo, la ciudad medieval en sí misma es el resultado inesperado del régimen feudal ${ }^{41}$; para nosotros el desarrollo poblacional y urbanístico del sistema que llamamos Vitoria —amén de otras razones

\footnotetext{
${ }^{41}$ "La ciudad medieval está en la lógica del régimen feudal, pero a la vez permanece ajena a esta lógica (...) En cierto modo, puede decirse que los primeros pasos del movimiento urbano no son algo externo ni contrario al régimen feudal, sino, a la inversa, una autotransformación del régimen, una labor de éste sobre sí mismo, lo que Toraine llamaria 'un fenómeno de historicidad'» (1980: 9 y 17).
} 
concurrentes - tiene mucho que ver con un impacto del sector de la construcción que fue mucho más fuerte, o mejor dicho, mucho más profundo de lo que los promotores de las distintas obras habían esperado en un primer momento ${ }^{42}$.

Quizá el principal fin de la muralla fuera proteger un cierto grupo humano, o la de construir un templo fuera la de articular con éste una circunscripción parroquial. Ambas pudieron ser las motivaciones primarias que promovieran el inicio de las respectivas empresas de construcción, ahora bien, los efectos que estos procesos de edificación produjeron fueron mucho más allá de lo evidente; la aldea de Gasteiz después de la construcción del primer recinto mural no sería sólo un asentamiento mejor protegido; además ahora contaría entre sus habitantes con nuevos efectivos demográficos, gentes especializadas en trabajos artesanales relacionados con el sector de la construcción (canteros, herreros, carpinteros, etc.) que durante varios años habían participado en las obras y que habían introducido novedades irreversibles en el tejido económico y social de la aldea.

\subsection{Fines latentes: Vitoria como memoria de sí misma}

Todos reconocemos de inmediato los fines manifiestos de una ciudad. Una urbe puede ofrecer la protección de una muralla, el libre intercambio de productos en la plaza del mercado, la solidaridad de una comunidad amplia, o permitir el dominio de un territorio; la lista podría ser mucho más larga. Estos fines manifiestos se perciben de una forma tan clara, que lo natural es que se impongan a la hora de interpretar el fenómeno urbano, de modo que si nos referimos a las murallas lo habitual es hablar de defensas, de guerra, de aislamiento o diferenciación ciudad/campo; si nos referimos al mercado lo natural es hablar de economía, de ferias, de productos en compra/ venta, de impuestos...; si hacemos referencia a las solidaridades comunitarias habría que hablar de sociedad, de parroquias, de cofradías, de gremios, de vecindades, etc.; o si percibimos la ciudad como un polo de control territorial, habrá que hablar de historia política, del poder de los señores, de la formación de los concejos, del control de la

${ }^{42} \mathrm{Al}$ hablar del despegue de las economías urbanas, si bien resulta natural hablar del mercado, del aumento de la productividad en el sector agrario y del progresivo desarrollo del sector artesanal en relación a los productos textiles o metalúrgicos, muy pocos son los esfuerzos a la hora de profundizar en el papel del sector de la construcción, aún cuando hace tiempo que se le reconoce como es una de las claves del despegue: "El 'take off' de la economía medieval se produjo en dos sectores base, no en sectores punta, la tierra y la construcción» (Le Goff, 1983: 67). monarquía o de la conformación de alfozes, entre otras muchas cuestiones de indudable relevancia. Es claro que estos fines manifiestos han primado a la hora de hacer historia de la ciudad.

Sin embargo, la ciudad también tiene fines latentes, es decir, no planificados o no percibidos conscientemente por aquellos que la habitan. La idea es de S. Johnson: "La ciudad tiene fines manifiestos; hay razones para que exista que generalmente sus habitantes reconocen: buscan la protección de una ciudad amurallada o el libre intercambio de productos. Sin embargo, la ciudad también tiene fines latentes: funciona como dispositivo de almacenamiento y recuperación de información» (2003: 96). Según Johnson las ciudades crearon interfaces ${ }^{43}$ de fácil manejo —al modo de las computadoras actuales antes de que nadie soñara con los ordenadores-; "las ciudades reunen las mentes y les asignan un lugar coherente. Los zapateros se instalan cerca de los zapateros, y los fabricantes de botones cerca de otros fabricantes de botones. Las ideas y los bienes fluyen dentro de estos conglomerados en una 'polinización cruzada' productiva, asegurando que las buenas ideas no mueran en el aislamiento rural» (Ibidem: 96-97).

De hecho, el sistema de barrios de la ciudad funciona como una suerte de interfaz de usuario por la misma razón que las interfaces de un ordenador tradicional (Fig. 19): hay límites para la cantidad de información que nuestros cerebros pueden manejar en un momento dado. El urbanismo de la ciudad contribuye -incluso en los casos más caóticos- a que las ciudades sean más inteligibles para sus habitantes, y probablemente la forma medieval de denominar las calles, constituye el mejor ejemplo de ello. Los nombres de las calles del Casco Antiguo de Vitoria-Gasteiz son de sobra elocuentes; Correría, Zapatería, Cuchillería, Herrería, Pintorería, Brullería, etc.

Esta perspectiva nos ayuda a percibir el urbanismo también como una herramienta de gestión de información, un instrumento que contribuye a que ciertos elementos de la vida urbana pasen de generación en generación, precisamente porque dichos elementos están asociados a una estructura física que tiene su propia durabilidad (Johnson, 2003: 96-97). Un buen ejemplo de esto lo constituye el propio registro estratigráfico, que no es sino materia in-

\footnotetext{
${ }^{43}$ No confundir con el uso de 'interfaz' en terminología arqueológica. Aunque en su estructura conceptual la 'interfaz' arqueológica guarda importantes similitudes con la 'interfaz' de las ciencias de la información, el uso que hace Johnson de este vocablo es de este último tipo. Entiéndase por lo tanto como el modo en que el ordenador establece la comunicación con el usuario, habitualmente a través de la pantalla, donde se nos presentan en forma de gráficos o iconos, los elementos o acciones que podemos realizar con el ordenador, la estructura de archivos del
} disco duro, etc. 


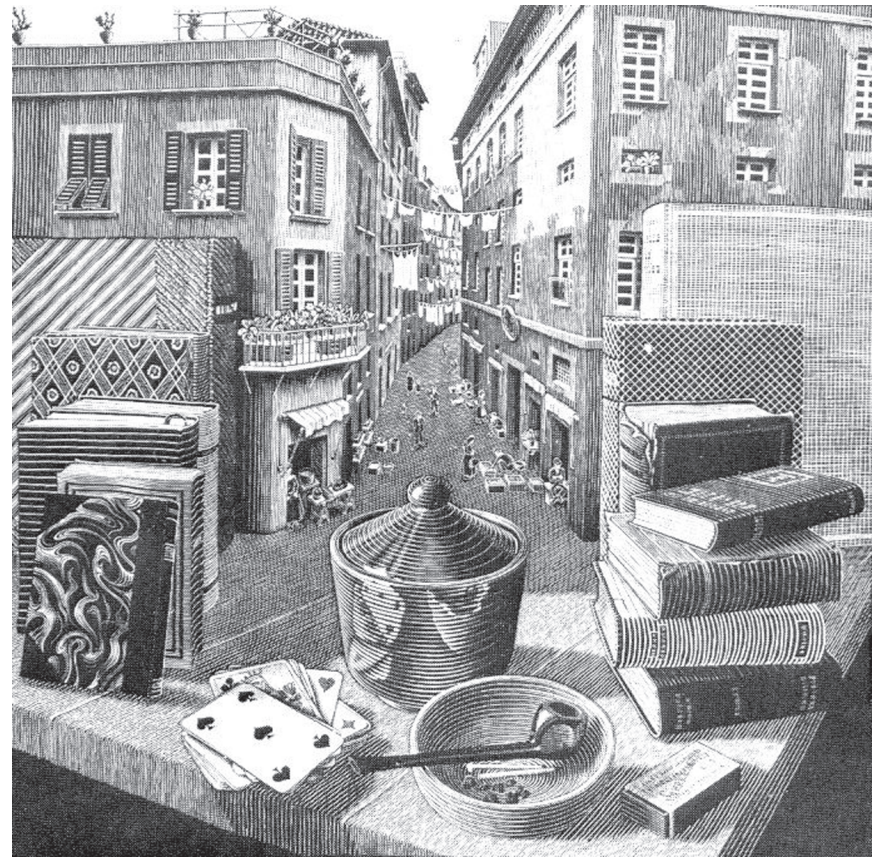

Fig. 19. M. C. Escher, Naturaleza muerta con calle. La ciudad como biblioteca. «Uno se adentra por las calles llenas de enseñas que sobresalen de las paredes. El ojo no ve cosas sino figuras de cosas que significan cosas: las tenazas indican la casa del sacamuelas, el jarro la taberna (...) La mirada recorre las calles como páginas escritas: la ciudad dice todo lo que debes pensar» I. Calvino, Las ciudades invisibles

formada, almacén de información histórica, que es la que nosotros como arqueólogos intentaremos recuperar para reconstruir la evolución del tejido urbano de Gasteiz.

\section{LA IDEA DE COMPLEJIDAD DE LOS SISTEMAS}

A lo largo de este artículo nos hemos esforzado por sintetizar en unas pocas palabras las características principales que rigen el pensamiento de sistemas complejos, tratando de evidenciar que, con ser la perspectiva por nosotros escogida para profundizar en el conocimiento de la urbe, ésta transciende lo arqueológico, lo histórico, lo social, lo económico o lo político. En realidad, el concepto de sistema complejo ha superado las barreras disciplinares, insertándose desde hace décadas en el discurso de prácticamente todas las ciencias, si bien hay que reconocer que esta modalidad de pensamiento sistémico, con todas sus implicaciones, aún parece muy lejos de adquirir una corporeidad y coherencia suficientes (Capra, 1998: 28-31).

Conviene insistir en estas últimas líneas, que la noción de sistema está íntimamente ligada a la idea de complejidad (particularmente si nos referimos al estudio del ámbito urbano), hasta el punto de que algunos especialistas no dudan en recurrir con cierta frecuencia a expresiones mixtas, del tipo "complejidad sistémica»: "Existe también el sentido de complejidad como sistema autoorganizado, más en la línea del Instituto Santa Fe que de la escuela de Frankfurt. Este tipo de complejidad vive en un nivel superior; describe el sistema de la ciudad en si mismo y no su recepción empirica por parte del habitante. La ciudad es compleja porque abruma, sí, pero también porque tiene una personalidad coherente, una personalidad que se autoorganiza a partir de millones de decisiones individuales, un orden global construido a partir de interacciones locales" (Johnson, 2003: 37).

La «complejidad sistémica» es además responsable de que arqueólogos e historiadores dispongamos de la materia prima fundamental en nuestro trabajo: el tiempo. La extensión de la siguiente cita merece la pena: «El tiempo aparece sólo al alcanzarse cierto nivel de complejidad. Si analizamos sistemas muy simples, como por ejemplo un péndulo ideal-sin fricción-, no tenemos forma de distinguir entre el pasado y el futuro. Si pasamos una película que muestra solamente el movimiento de un péndulo, no importa si hacemos funcionar el proyector hacia adelante o hacia atrás: siempre veremos lo mismo. Podemos decir que se trata de una película reversible. Lo mismo sucede si consideramos el movimiento de la Tierra alrededor del Sol; no hay irreversibilidad asociada a este proceso. Todo problema surge porque se ha considerado a los sistemas simples como modelos del universo. De esta forma, la física clásica terminó concluyendo que el tiempo no existe, y es por eso que yo pienso que sólo descubriremos el tiempo al descubrir los sistemas complejos. La historia de la arquitectura nos muestra un ejemplo muy interesante. Si tomamos un ladrillo de una casa persa y uno de una casa del siglo XIX no habrá básicamente grandes diferencias. Pero si pasamos a un nivel de mayor complejidad y consideramos un edificio completo, la discrepancia entre una construcción persa, una gótica o una del siglo XIX será enorme. Siempre he pensado que el tiempo se descubre a través de la complejidad y, en alguna medida, esto se ha comprobado en los últimos años». Son palabras del Nobel de Química I. Prigogine (Najmanovich, 1991: 3-4).

\section{SISTEMAS COMPLEJOS: ENTRE PROCESUALISMO Y POST-PROCESUALISMO}

Como hemos venido comentando a lo largo del artículo, las diversas implicaciones del pensamiento sistémico y el universo de la complejidad, están siendo exploradas por científicos de todo tipo; zoólogos, biólogos, antropólogos físicos y sociales, etc. y entre ellos, a modo de "pioneros", algunos arqueólogos. Cabría destacar entre estos últimos, puesto que además no lo hemos hecho con anterioridad, a autores como J. L. Bintliff (1999), R. Lewin (1993), a S. E. Van der Leeuw y a J. McGlade (1997) quienes han 
profundizado en varias de las cuestiones que hemos tratado en este texto. Uno de sus méritos más remarcables -al menos a nuestro juicio-, es haber conseguido cuestionar de forma bien argumentada la supuesta incompatibilidad de los enfoques procesual y post-procesual. Nos gustaría dedicar a esta cuestión parte de las últimas líneas.

\subsection{La palanca del surtidor de Broad Street}

A principios de septiembre 1854, un terrible brote de cólera asoló las calles del Soho londinense. Durante aquellos días, prácticamente contrarreloj, dos hombres — John Snow y Henry Whitehead - llevan a cabo una investigación que, aparte de frenar el contagio, acabará sacudiendo los cimientos de la comunidad científica victoriana. La labor de ambos resultó fundamental para la resolución del problema, pero lo insólito del caso es que no trabajaron en equipo; de hecho, en un principio ni se conocían. Sus formas de ver el mundo eran además muy distintas. Snow era médico, mientras que Whitehead era párroco; aquél visualizaba el problema desde la perspectiva de los virus y las formas de contagio, éste lo leía en los rostros de las personas del barrio a quienes atendía espiritualmente.

Como es lógico, Snow enfocó el problema un tanto despersonalizadamente. No era que no le importaran las personas, pero creía que la epidemia sólo se podría detener, catalogando y ordenando fríamente los datos. Contrariamente a lo que entonces pensaban los científicos, Snow tenía el convencimiento de que el cólera se transmitía por el agua y no por el aire, de modo que tomó un plano de la zona y empezó a marcar con un punto el lugar de los domicilios con casos de cólera y el enclave de las fuentes que abastecían el distrito. Recurriendo a una centenaria técnica matemática que después fue conocida como 'diagrama Voronoi', extrajo una conclusión clara; el epicentro del brote de cólera era el surtidor de Broad Street. Sin embargo, a pesar del fundamental hallazgo, la comunidad científica y las autoridades londinenses no le concedieron valor.

Whitehead por su parte tenía un contacto muy directo con la epidemia. Diariamente visitaba las casas de los afectados para tratar de reconfortarles tanto en lo material como en lo espiritual. Era también un hombre metódico -confeccionó su propia lista de afectados-, pero sobre todo era alguien que conocía muy bien la mentalidad de los parroquianos, sus costumbres, sus creencias, sus hábitos. Sin embargo, a pesar de su empeño, Whitehead no era capaz de visualizar el problema de forma global: hasta que tuvo la oportunidad de contemplar el mapa del brote elaborado por Snow.
Aunque en un principio Whitehead también era de los que pensaba que el cólera se transmitía por el aire, tuvo una corazonada: conocía de cerca el primer caso de cólera en el barrio, y sabía que ése se había producido precisamente en el 40 de Broad Street, a pocos metros del surtidor señalado por el médico ¿habría efectivamente alguna conexión entre el agua que manaba de aquella fuente y el brote epidémico?

Efectivamente la había. Las heces del primer afectado habían sido arrojadas a un pozo negro que filtraba parte de su contenido a la canalización que a su vez alimentaba el citado surtidor. Con todo, el agua presentaba el saludable aspecto de siempre, de modo que las gentes del barrio siguieron sirviéndose de él. Así había empezado todo.

Sin embargo, los medios para frenar el contagio no fueron puestos de inmediato ¿por qué? Es aquí donde queríamos llegar. Con el hallazgo del patrón, la posterior localización del caso índice y de la secuencia de arranque de la epidemia, el primario análisis de sistemas de Snow, aportaba pruebas fundamentales, pero sólo circunstanciales (recordemos que por entonces las bacterias aún no eran reconocidas como causantes de enfermedades); para detener aquella ruleta mortal aún había que superar otro obstáculo. Ahora era necesario actuar sobre la sociedad, sobre los individuos y el sistema de creencias vigente. Esa fue la contribución más genuina del reverendo Whitehead; dando crédito (casi por intuición) a la hipótesis de Snow, concentró todos sus esfuerzos en argumentar y tratar de superar supersticiones, logrando finalmente convencer a las gentes de barrio, a la Junta Parroquial y al reaccionario Comité de Sanidad londinense sobre el peligro del agua del surtidor. Esta labor fue extremadamente compleja y más lenta de lo deseable, pero al final consiguió que se retirara la palanca de la fuente. Sólo entonces la epidemia cesó (Johnson, 2008).

En este episodio (fundamental para la ciencia, particularmente para la epidemiológica), Snow muestra una predominante inclinación por la búsqueda de patrones, por la modelización e identificación de procesos de retroalimentación; el modo en que actuaba era el del pensador sistémico. Whitehead por su parte se centraba en los aspectos sociales, profundizaba en el conocimiento de los individuos, caso por caso, observaba los hábitos, las supersticiones. Cada uno desde su enfoque había conseguido dar con algunas de las claves del problema, y sin embargo, es muy probable que si no hubieran tenido conocimiento mutuo en el tramo final de sus respectivos procesos de investigación, nunca hubieran llegado a una solución.

Desde nuestro punto de vista, el "problema» de la interpretación en arqueología tiene ciertas semejanzas. El 
entendimiento entre las perspectivas procesual y postprocesual resulta imprescindible para aspirar a nuevos horizontes de conocimiento, y sin embargo la polarización sigue bastante marcada; la palanca sigue en el surtidor. Según Shanks, la arqueología procesual sigue siendo la ortodoxia dominante en la arqueología mundial, mientras que la crítica post-procesual esta llegando al extremo de ser caricaturizada (2005).

Quizá el modo de matizar las diferencias comience precisamente por evitar este tipo de reduccionismos y "caricaturizaciones», pero en ambos sentidos; evitando por ejemplo tachar, sin apenas matices, al enfoque procesual de neopositivista, cuando no está demostrado que exista una conexión necesaria entre la búsqueda de modelos, estructuras y patrones y el positivismo per se (Mcglade y Van der Leeuw, 1997: 8); o dejando de lado ese supuesto —un tanto maniqueo- por el cual la crítica post-procesual se consagra al individuo al tiempo que rechaza de plano las generalizaciones de la ciencia procesual (Shanks, 2005).

$\mathrm{Si}$ algo creemos haber aprendido a apreciar mediante la perspectiva de sistemas complejos -y el paradigma ecológico que lo sustenta- es que las tendencias de pensamiento arqueológico actuales son mucho más asertivas que integrativas. Nuestra apuesta personal con el enfoque de sistemas complejos aplicado al urbanismo de Vitoria nace de ese convencimiento, y de creer que existe la necesidad de compensar los valores asertivos de competición, expansión, dominación, con un pensamiento más abierto a lo holístico, a lo cooperativo, a lo no-lineal; en definitiva, el 'rhizomes-thinking' de Shanks (1991: 35).

\section{7. ¿OTRA «ARQUEOLOGÍA DE LA COMPLEJIDAD»?}

A la vista de todo esto y como conclusión no podemos evitar preguntarnos ¿es ésta la Complejidad de la que habla Brogiolo? Sin duda, la Archeologia della complessità en cuanto que Arqueología delle relazioni, nos remite al horizonte del pensamiento sistémico. También apuntan en esa dirección algunos de los otros aspectos sobre los que el citado autor reclama atención: "una arqueología diacrónica que trata de definir la transformación de los ambientes socioculturales, desde los primeros testimonios organizados hasta la edad preindustrial, con el objetivo de reconstruir la evolución en el largo plazo de la identidad de un territorio y de las comunidades que lo han habitado» (2007: 33). Incluso su propuesta de recuperar de algún modo los Annales discurre en ese sentido (como él, el propio Bintliff insiste en la influencia de esta corriente en los más recientes enfoques sistémicos, 2004: 174-194). Con todo, nuestra pregunta sólo pretende dilucidar de qué se habla cuando se habla de Arqueología de la Complejidad ¿̇e la complejidad sistémica?, ¡la de las llamadas Ciencias de la Complejidad? ¿o de otra cosa (acaso un nueva nomenclatura con efectos restringidos "puertas adentro» de la propia Arqueología)?

La cuestión nos parece clave; primero porque si lo que se pretende con tal formulación no es adaptar el sistema conceptual del nuevo enfoque a la ciencia arqueológica, estamos corriendo el serio peligro de automarginarnos, al suplantar con distintos contenidos una terminología que se está gestando interdisciplinarmente, precisamente con la vocación de generar entendimiento entre las diferentes ciencias humanas y experimentales. Segundo, porque quizá con el ansia de aggiornamento nos exponemos con demasiada gratuidad al riesgo de la moda; por más que se plantee casi como la alternativa definitiva, es difícil sustraerse al pensamiento de que la Arqueología de la Complejidad y de las relaciones no es sino otro producto coyuntural, cuando aún prácticamente no-nata, tacha al resto de "arqueologías» precisamente como productos de una efervescencia pasajera ${ }^{44}$.

Como creemos habrá quedado claro a lo largo del texto, somos por supuesto partidarios de introducir los principios del pensamiento sistémico o el universo de la complejidad en Arqueología de la Arquitectura, o sencillamente dentro de la Arqueología (la cuestión de la denominación resulta a nuestro entender secundaria). Ahora bien, creemos que para superar cualquier marco teórico supuestamente obsoleto, no conviene sugerir su presunta obsolescencia y acompañar tal argumentación con una nueva denominación. Creemos que es necesario entrar en una definición más explícita de los nuevos principios en que se sustenta, asumiendo por así decir, esa estética del Centro Pompidou que mencionáramos al principio. Esto es lo que estamos intentando en nuestros trabajos, y es lo que hemos ensayado en este artículo sobre los Sistemas Complejos.

\section{Bibliografía}

Azkarate, A. et alii (2002), Arqueología de la Arquitectura: definición disciplinar y nuevas perspectivas, Arqueología de la Arquitectura, no 1, pp. 7-10. (http:// arqarqt.revistas.csic.es/index.php/arqarqt/article/viewFile/1/1).

Azkarate, A. y García Gómez, I. (2004), Las casas-torre bajomedievales. Análisis sistémico de un proceso de reestructuración espacial/territorial, Arqueología de la Arquitectura, no 3, 7-37.

\footnotetext{
44 "Dall'Archeologia dei segmenti, quali sono l'Archeologia dell'Architettura e le tante etichette inventate dal nulla in questi anni di fervorosa e talora imaginativa recerca teorica nel solco dell'Archeologia post-processuale (Archeologia storica, Archeologia industriale, Etnoarcheología, Archeologia attualistica, Landscape Archaeology, Material Cultura Studies, Rescue Archaeology), è forse più interessante proporsi un'Archeologia della complessità e delle relazioni» (Brogiolo, 2007: 32-33).
} 
Azkarate, A. (e.p.), La Arqueología de la Arquitectura como Arqueología de la Arquitectura, en J. A. Quirós Castillo (ed.), El fin de la Arqueología en los inicios del siglo XXI, Madrid.

Baldini, M. (ed. 1995), Gli aforismi di Sherlock Holmes, Milán.

Barel, Y. (1980), La ciudad medieval. Sistema social-Sistema urbano, Madrid.

Bertalanffy, L. von (1976), Teoría general de los sistemas, Madrid.

Bintliff, J. L., (1999), Structure and Contingency in the Evolution of Life: Human Evolution and Human History, Londres.

Bintilff, J. L., (2004), A companion to Archaeology, Londres.

Bois, G. (2001), La gran depresión medieval: siglos XIV-XV. El precedente de una crisis sistémica, Valencia.

Brogiolo, G. P. (1988), Archeologia delledilizia storica, Como.

Brogiolo, G. P. (2007), Dall'Archeologia dell'architettura all'Archeologia della complessità, Pyrenae, 38, vol. I, pp. 7-38.

Butzer, K.W. (1982), [1989, ed. Española], Arqueología, una ecología del hombre, Barcelona.

Calvino, I. (1974), Las ciudades invisibles, Buenos Aires.

Caniggia, G. y Maffei, G. L. (1995), Tipología de la edificación. Estructura del espacio antrópico, Madrid.

Capra, F. (1998), La trama de la vida. Una nueva perspectiva de los sistemas vivos, Barcelona.

Carandini, A. (1996), Storie dalla terra. Manuale di scavo archeologico, Turín.

Criado, F. (1993), Límites y posibilidades de la Arquelogía del Paisaje, Revista de prehistoria y arqueología de la Universidad de Sevilla, no 2, pp. 9-56. (http:// dialnet.unirioja.es/servlet/fichero_articulo?codigo=176603\&orden=0)

Criado, F. (1999), Del terreno al espacio: planteamientos y perspectivas para la arqueología del Paisaje, CAPA: cadernos de arqueoloxía e patrimonio, ${ }^{\circ} 6$, pp. 1-82. (http://www-gtarpa.usc.es/descarga/CapaTapa/CAPA/CAPA6.pdf)

Criado, F. (2006), ¿Se puede evitar la trampa de la subjetividad?: sobre arqueología e interpretación, Complutum, no17, pp. 247-254. (http:// revistas.ucm.es/ghi/11316993/articulos/CMPL0606110247A.PDF).

Delgado, M. (2007), Sociedades movedizas. Pasos hacia una antropología de las calles, Barcelona.

Erlande-Branderburg, A. (1989), La Cathédrale, Poitiers.

Ernst, B. (1994), El espejo mágico de M.C.Escher, Colonia.

Fernádez-Galiano, L. (1991), El fuego y la memoria. Sobre arquitectura y energía, Madrid.

Flannery, K. V. (1968), Archaeological systems theory and early Mesoamerica, en Meggers, B. J. (ed.), Anthropolical Archeology in the Americas, Washington, pp. 67-97.

García Gómez, I. (2003), Claves para el conocimiento de la configuración espacial de una torre banderiza: la Torre de Murga (siglos XIV-XV), Arqueología de la Arquitectura, no 2, pp. 131-138.

Harris, E. C. (1991), Principios de Estratigrafía Arqueológica, Barcelona.

Harris, M. (2006), Vacas, cerdos, guerras y brujas, Madrid.

Hillier, B. y Hanson, J. (2001), The social logic of space, Cambridge.

Hodder, I. (1994), Interpretación en Arqueología. Corrientes actuales, Barcelona.

Hofstadter, D. R. (2005), Gödel, Escher, Bach un Eterno y Grácil Bucle, Barcelona.

Johnson, S. (2003), Sistemas emergentes. O que tienen en común hormigas, neuronas, ciudades y software, Madrid.
Johnson, S. (2008), El mapa fantasma. La historia real de la epidemia más terrorifica vivida en Londres, Madrid.

Kelly, K. (2002) Las nueve leyes de Dios, Oeste, no 15, pp. 136-145.

Krugman, P. (1997), La organización espontánea de la economía, Barcelona.

Kuhn, T. S. (2001), La estructura de las revoluciones cientificas, Madrid.

Lefebvre, H. (1972), La revolución urbana, Madrid.

Le Goff, J. (1983), El tiempo del trabajo en la crisis del siglo XIV: del tiempo medieval al tiempo moderno, en Tiempo, cultura y trabajo en el Occidente medieval, Madrid, pp. 63-75.

Lewin, R., (1993) Complexity: Life at the Edge of Chaos, Londres.

Lewis-Gaddis, J. (2004), El paisaje de la historia. Cómo los historiadores representan el pasado, Barcelona.

Lynch, K. (2004), La imagen de la ciudad, Barcelona.

Mannoni, T. y Giannichedda, E. (2004), Arqueología de la producción, Barcelona.

Najmanovich, D. (1991), Entrevista a Ilya Prigogine: ¿nuevos paradigmas?, Zona Erógena, no 10, pp. 1-6 (http://www.insumisos.com/lecturasinsumisas/ Nuevos\%20Paradigmas.pdf).

Prigogine, I. (2005), El nacimiento del tiempo, Barcelona.

Saunders, T. (1990), The Feudal Construction of Space: Power and Domination in the Nucleated Village, en Samson, R. (ed.), The Social Archaeology of Houses, Edimburgo, pp. 181-196.

Samson, R. (ed. 1990), The Social Archaeology of Houses, Edimburgo.

Samson, R. (1990), Introduction, en Samson, R. (ed.), The Social Archaeology of Houses, Edimburgo, pp. 1-18.

Saura i Carulla, C. (2003), Arquitectura y medio ambiente, Barcelona.

Santos, M. (2000), La naturaleza del espacio, Barcelona.

Schelling, T. (1978), Micromotives and Macrobehavior, Nueva York.

Schlögel, K. (2007), En el espacio leemos el tiempo. Sobre Historia de la civilización y Geopolítica, Madrid.

Shanks, M. (1991), Experiencing the Past, Londres/Nueva York.

Shanks, M. y Tilley, C. (1992), [1996 ed. consultada] Re-constructing Archaeology: theory and practice, Londres.

Shanks, M, (2005), Post-preocessual archaeology and after, en Chippindale, C. y Maschner, H., Handbook of Archaeological Methods and Theories. (http:// metamedia.stanford.edu/ - mshanks/writing/postproc.pdf).

Solé, R. (2009), Redes complejas, Barcelona.

Unwin, S. (2003), Análisis de la Arquitectura, Barcelona.

Van der Leeuw, S. E. y McGlade, J. (1997) Time, Process and Structures Transformation in Archaeology, Londres.

White, L. (1973), Tecnología medieval y cambio social, Buenos Aires.

Wolman, A. (1982), El metabolismo de las ciudades, en Davis, K. et alii, La ciudad, Madrid.

Wright, R. (2005), Nadie pierde. La teoría de juegos y la lógica del destino humano, Barcelona. 